\title{
Defense Attorney Bias and the Rush to the Plea
}

\author{
Molly J. Walker Wilson*
}

"We have rejected an approach to individual liberties that 'abstracts from the right to its purposes, and then eliminates the right."'

- Justice Antonin Scalia ${ }^{1}$

\section{INTRODUCTION}

The pervasiveness of plea bargains in our criminal justice system is of concern to many, and scholars in the legal academy have often been critical of the practice. ${ }^{2}$ One reason for the unease is that plea deals are often made quickly and without adequate investigation or consultation. Once a deal is secured, the defendant forfeits the protections that come with a trial. Because of the number of defendants and limitations on resources, prosecutors and public defenders both depend upon defendants taking deals and staying out of court. ${ }^{3}$ The public relies upon ethical exercises of prosecutorial discretion, and professional mandates of impartiality (for judges) and zealous representation (for criminal defenders) to protect criminal defendants. These dictates, in concert with

\footnotetext{
* Professor of Law and Psychology, Saint Louis University School of Law. I am indebted to my fellow panelists at the 2015 American Bar Association National Conference on Professional Responsibility, Tigran Eldred, Robert Prentice, and Cathy O'Grady, for insights that prompted me to write this Article. Credit goes to my research fellows, Jacob Grimes, Amanda Hayden, and Bradley Tharpe for their diligent work, research, and editing of this Article.

1. Indiana v. Edwards, 554 U.S. 164, 185 (2008) (Scalia, J., dissenting) (citing United States v. Gonzalez-Lopez, 548 U.S. 140, 145 (2006)).

2. See Albert W. Alschuler, The Changing Plea Bargaining Debate, 69 CAL. L. REV. 652 (1981); Albert W. Alschuler, The Defense Attorney's Role in Plea Bargaining, 84 YALE L.J. 1179 (1975) [hereinafter The Defense Attorney's Role in Plea Bargaining]; Albert W. Alschuler, The Trial Judge's Role in Plea Bargaining, Part I, 76 ColuM. L. Rev. 1059 (1976); Stephen J. Schulhofer, Is Plea Bargaining Inevitable?, 97 HARV. L. REV. 1037 (1984); Donald G. Gifford, Meaningful Reform of Plea Bargaining: The Control of Prosecutorial Discretion, 1983 U. ILL. L. REV. 37 (1983); Kenneth Kipnis, Plea Bargaining: A Critic's Rejoinder, 13 LAW \& SoC'Y ReV. 555 (1979); John H. Langbein, Torture and Plea Bargaining, 46 U. CHI. L. REV. 3 (1978); Robert E. Scott \& William J. Stuntz, Plea Bargaining as Contract, 101 YALE L.J. 1909, 1967-68 (1992) [hereinafter Plea Bargaining as Contract].

3. David P. Leonard, Waiver of Protections Against the Use of Plea Bargains and Plea Bargaining Statements After Mezzanatto, 23 CRIM. JUST., Fall 2008, at 8, 9 ("Both sides know that settlement is a necessity in the criminal justice system. In fact, the system cannot function unless only a small percentage of cases are tried.”).
} 
constitutional rules and general oversight by higher courts, lead insiders and some observers to argue that while the system is imperfect, it is adequate. However, structural features of the criminal justice system create inevitable psychological pitfalls. Heavy caseloads for prosecutors and defense lawyers, along with broad prosecutorial discretion, and perverse incentives exacerbate problems of cognitive bias, motivated reasoning, and ethical blindness. A number of scholars have written about behavioral biases in prosecutorial decision-making, but biases that influence criminal defense lawyers have received little attention. ${ }^{4}$ This is an important omission because defense counsel is often the proxy for the defendant for purposes of decision-making.

The criminal defense attorney is presumed to be the best judge of what is in the best interest of her client. There are some good reasons for this; attorneys who represent indigent criminal defendants almost always have a better understanding of the law and criminal court procedures. In the case of public defenders, who represent the vast majority of indigent defendants, experience with the courts and local judges and prosecutors can be invaluable. In addition to knowledge and experience, a criminal defense attorney can bring some objectivity to decisions made in the best interests of the defendant. Finally, a good lawyer will act in the interest of her client, even when the client seems to be bent on self-destruction or is putting the interests of another party ahead of his own.

However, for every advantage offered by the defense attorney, there is a reason to worry that the attorney's choices are tainted. Even aspects of the lawyer's past practice that are arguably beneficial can ultimately be a liability. One example is the lawyer's familiarity with the system. The closer the lawyer is to the process, the better she knows the players, and the more times she has seen a client go through the process, the less likely she is to look critically at how the process is impacting the defendant.

The most experienced defense attorney is the public defender, who gains a great deal of experience by virtue of having an endless supply of needy clients. The heavy caseload that results in the wealth of experience for these lawyers also severely limits the amount of attention public defenders can give individual defendants. Not only does the public defender not have the luxury of carefully considering the various options available to her client, she may often not even have the time to

4. There are some notable exceptions. For example, see Tigran W. Eldred, Prescriptions for Ethical Blindness: Improving Advocacy for Indigent Defendants in Criminal Cases, 65 RUTGERS L. REV. 333, 357 (2013) [hereinafter Prescriptions for Ethical Blindness]. 
gather basic information. In many cases, more serious cases become a priority, preventing the defense attorney from spending the time to carefully interview and investigate the cases of clients with less serious charges. As a result, the attorney does not have an adequate basis to determine what is best for her client, what he wants, or even what he knows about the alleged crime. ${ }^{5}$ Meanwhile, the requirements of many clients force the public defender to make hasty decisions and to balance the needs of each individual defendant against those of others who are waiting in the wings.

Traditional analyses of the role of the public defender in the criminal justice system have not explored how limited resources can exacerbate decisional biases, and have therefore underestimated the public-defense crisis. Empirical research has provided a wealth of information regarding how cognitive and social biases can influence choice in a variety of contexts. ${ }^{6}$ This research has received widespread attention from the most influential thinkers and policy makers, and the legitimacy of using behavioral data to shape policy and practice is well established. Yet, although psychological findings have been applied to consumer contexts, voting behavior, economic trends, politics, judicial analysis, and many other areas, the behavioral science lens is rarely applied to public defenders. And yet, research on cognitive and behavioral biases has special importance for the public defender context.

Priming, anchoring, belief perseverance, and the confirmation and over-confidence biases lead public defenders to form an impression of a case based upon incomplete evidence, which results in the failure to adequately discount questionable inculpating evidence and the

5. This article does not address the thorny question of autonomy in decision-making for criminal defendants with identified mental illness. As the Court pointed out in Edwards, "a right of self-representation at trial will not 'affirm the dignity' of a defendant who lacks the mental capacity to conduct his defense without the assistance of counsel." 554 U.S. at 176 (quoting McKaskle v. Wiggins, 465 U.S. 168, 176-77 (1984)). Rather, this article's scope is limited to the allocation of decision-making power between a mentally competent criminal defendant and her attorney.

6. Law reviews are replete with invocation of behavioral science in legal decision contexts. See, e.g., Donald C. Langevoort, Symposium, Behavioral Theories of Judgment and Decision Making in Legal Scholarship: A Literature Review, 51 VAND. L. REV. 1499 (1998); see also Russell Korobkin, What Comes After Victory for Behavioral Law and Economics?, 2011 U. ILL. L. ReV. 1653 (2011); Richard H. Thaler, The Winner's Curse: Paradoxes and ANOMALies of ECONOMIC LIFE (Princeton 1994) (1991); Daniel A. Farber, Toward a New Legal Realism, 68 U. Chi. L. Rev. 279, 303 (2001) (reviewing Behavioral LaW \& EConomics (Cass R. Sunstein ed., 2000)); Owen D. Jones, Time-Shifted Rationality and the Law of Law's Leverage: Behavioral Economics Meets Behavioral Biology, 95 Nw. U. L. REv. 1141 (2001). Articles dating back to the middle of the twenty-first century reveal that early applications of behavioral science to legal norms foreshadowed what was to come: Myron Roomkin \& Roger I. Abrams, Using Behavioral Evidence in NLRB Regulation: A Proposal, 90 HARV. L. ReV. 1441 (1977); Arthur Selwyn Miller, On the Interdependence of Law and the Behavioral Sciences, 43 TEX. L. REV. 1094 (1965). 
undervaluing of exculpating evidence. Research on motivated reasoning suggests that public defenders will be overly confident and self-serving in their evaluations to cases, and will be "blind" to legitimate ethical issues in how they represent their clients. A number of features of the criminal justice system increase the defense attorney's susceptibility to these biases. First, when cognitive resources are stretched, as is the case when a public defender is representing a large number of defendants, biased judgments are more likely. Psychologists refer to this type of situation as high "cognitive load." Scores of studies have shown that cognitive shortcuts - also called "heuristics"- are far more likely when individuals are under cognitive load. ${ }^{8}$ Hence, a public defender is more vulnerable to these biases than she would be were she not under severe time and resource constraints. Another feature of the criminal justice system that can contribute to bias is the process by which law enforcement extracts information from suspects. Common police interrogation practices are known to encourage false confessions. ${ }^{9}$ In addition to influencing police, prosecutors, and jurors, confessions also impact defense attorney evaluations of the strength of a case.

The same factors that lead attorneys to make errors-limited resources and time and early exposure to the prosecutor's evidence-also make the plea more attractive to the defense attorney. ${ }^{10}$ The vulnerable defendant who is most at risk for falsely confessing is also the defendant who is most likely to agree to accept a plea, even when he is innocent. ${ }^{11}$ The more harried and rushed the defense attorney, the less likely she is to perceive weaknesses in the prosecution's case. When a defense attorney has very little time to spend with her client, research tells us that the client is likely to lack confidence in the quality of representation, and

7. See Anuj K. Shah \& Daniel M. Oppenheimer, Heuristics Made Easy: An Effort-Reduction Framework, 134 PSYCHOL. BULL. 207, 207, 212 (2008). ("As the demands on limited cognitive resources increase, people may employ methods or strategies that reduce the effort they expend on computation. We will therefore refer to heuristics as methods that use principles of effort-reduction and simplification. By definition, heuristics must allow decision makers to process information in a less effortful manner than one would expect from an optimal decision rule.").

8. Id. at 207.

9. See generally Saul M. Kassin et al., Police-Induced Confessions: Risk Factors and Recommendations, 34 LAW \& HUM. BEHAV. 3 (2010).

10. "You've got so many cases, limited resources, and there's no relief. You go to work, you get more cases. You have to triage." Hannah Levintova, Jaeah Lee \& Brett Brownell, Charts: Why You're in Deep Trouble if You Can't Afford a Lawyer, MOTHER JONES (May 6, 2013) [hereinafter MOTHER JONES] (quoting Tanya Greene of the American Civil Liberties Union), http://www.motherjones.com/politics/2013/05/public-defenders-gideon-supreme-court-charts.

11. See infra notes 117, 141, 156 and accompanying text (discussing the pressures that cause defense attorneys and innocent defendants to accept plea bargains). 
may be more likely to view a deal as being his best choice. ${ }^{12}$ Under these circumstances, an innocent defendant may conclude that his best bet is to take the deal and avoid the risk of a longer sentence. ${ }^{13}$

Even in the case of guilty defendants, accepting plea bargains without carefully weighing the strength of the case is problematic. Criminal defendants likely underestimate the opportunity costs associated plea deals - namely, giving up the right to force the prosecutor to prove her case. Considering what the defendant is surrendering, the deals offered by prosecutors do not sufficiently discount the penalty. Because prosecutors routinely overcharge, ${ }^{14}$ many charges would not hold up at trial-when the burden of proof is on the state. Accordingly, the "discount" offered with a plea is often close to what the defendant would receive at trial anyway, in which case the defendant would fare best by going to trial. A trial would afford him Fifth, Sixth, and Fourteenth Amendment protections, as well as judicial oversight and a variety of other procedural benefits. ${ }^{15}$

Judges, who suffer the effects of overloaded dockets, generally encourage plea bargains, and courts rarely provide defendants with afterthe-fact remedies for shabby lawyering-particularly where plea bargains are concerned. ${ }^{16}$ Meanwhile, plea bargains are subject to the least amount of supervision because they occur behind closed doors and away from even minimal judicial supervision. So, although defense

12. Id.

13. A number of articles have pointed to the risk of an increase in conviction for innocent defendants as one of the primary objections to the proliferation of the plea bargain. See Michael O. Finkelstein, A Statistical Analysis of Guilty Plea Practices in the Federal Courts, 89 HARV. L. REV. 293, 295 (1975); Plea Bargaining as Contract, supra note 2, at 1950-51; David L. Shapiro, Symposium, Should a Guilty Plea Have Preclusive Effect?, 70 IowA L. Rev. 27, 40-41 (1984); Oren Gazal-Ayal, Partial Ban on Plea Bargains, 27 CARDOzo L. ReV. 2295, 2297-2300 (2006) (arguing for a partial ban on plea bargaining to reduce the likelihood innocent defendants will plead guilty); Andrew D. Leipold, How the Pretrial Process Contributes to Wrongful Convictions, 42 AM. CRIM. L. REV. 1123, 1154 (2005).

14. Timothy Lynch, The Case Against Plea Bargaining, 26 REg., no. 3, Fall 2003, at 24, 24 ("There is no doubt that government officials deliberately use their power to pressure people who have been accused of crime, and who are presumed innocent, to confess their guilt and waive their right to a formal trial. We know this to be true because prosecutors freely admit that this is what they do.").

15. Id. at 26 ("Plea bargaining rests on the constitutional fiction that our government does not retaliate against individuals who wish to exercise their right to trial by jury.").

16. Jason Solomon notes that judges who are faced with the question of whether a defendant has been deprived of meaningful representation are unlikely to purposely look to social science data in order to determine whether an oversight, action or inaction was, or was not, harmless in terms of the impact on the jury's decision to convict. Jason M. Solomon, Causing Constitutional Harm: How Tort Law Can Help Determine Harmless Error in Criminal Trials, 99 Nw. U. L. REV. 1053, 1071 (2005). 
attorneys admit that they use psychological pressure to encourage their clients to accept deals, there is virtually no remedy available to defendants who regret their choice later.

In sum, defense lawyers are prone to biased decision-making and are incentivized to make concessions to get their clients' cases settled efficiently. Their choices are accorded deference by courts and members of the public, both for practical reasons and because of an assumption that lawyers make better decisions. Simultaneously, the criminal defendant's opinion regarding pretrial and trial decisions is minimalized, trivialized, or even mocked. There is widespread dismissal and even condemnation of efforts of defendants to take control of their cases. ${ }^{17}$

Criminal defendants themselves can serve as a check on the current quick-plead system. As some scholars have noted, "[o]verworked and underpaid defense lawyers frequently do not have the information or the resources to assess the government's case and accurately predict trial outcomes."18 The public defender often has very limited time to meet with her client, but the defendant has ready access to much of the information the lawyer does not. Some of this information is relevant to the choice of defense strategy. For example, the defendant may have a better sense for the motivations of witnesses, has better insight into the amount of risk he is comfortable assuming in weighing any proffered plea deal against going to trial.

Although many assume that criminal defendants make poor decisions, evidence suggests otherwise. Studies of outcomes in trials where defendants took control of their own defenses reveal that defendants do as well or better than criminal defense lawyers. ${ }^{19}$ Equally important, research reveals that criminal defendants who are substantially involved in planning and decision-making experience a range of positive effects, regardless of the ultimate disposition of their

17. Pamela R. Metzger, Fear of Adversariness: Using Gideon to Restrict Defendants' Invocation of Adversary Procedures, 122 YALE L.J. 2550, 2555-56 \& n.24 (2013) [hereinafter Fear of Adversariness] ("I note but lack the space to comment further upon the patronizing and dismissive way in which the ABA comment describes the defendant who seeks to assist counsel in a proceeding that puts the defendant - and the defendant alone - at risk of incarceration, or even death.").

18. Susan R. Klein, Aleza S. Remis \& Donna Lee Elm, Waiving the Criminal Justice System: An Empirical and Constitutional Analysis, 52 AM. CRIM. L. REV. 73, 75-76 (2015).

19. Erica J. Hashimoto, Defending the Right of Self-Representation: An Empirical Look at the Pro Se Felony Defendant, 85 N.C. L. REV. 423, 447-51 (2007) [hereinafter Defending the Right of Self-Representation]. Aggregated data from criminal trial outcomes suggests that bad attorney decisions are costly for criminal defendants. Almost a third of people exonerated through the use of DNA argued that their defense lawyer made poor choices. BRANDON L. GARRETT, CONVICTING THE INNOCENT: WHERE CRIMINAL PROSECUTIONS Go WRONG 205 (2011). 
case. $^{20}$ The science is clear; human beings do better on a range of measures when they take control of their own future outcomes.

This article challenges the current attorney-controlled, plea-bargain system of criminal justice and calls for a greater role for criminal defendant choice in pretrial decisions. The central claim of this Article is that defense attorneys are vulnerable to biases that influence their perceptions of their clients' cases and predispose them to be overly favorable to plea deals. Giving defendants more voice in pretrial choices will lead to more pretrial investigation and fewer ill-advised plea deals.

Part II of this Article discusses the psychological biases that influence defense attorney decision-making. These biases include those resulting from repeat experience with the criminal justice system, biases associated with a desire to confirm existing beliefs, and biases that are motivated by a need to preserve one's own positive self-concept. Part III delves into the phenomenon of the "meet-em-and-plead-em" culture of public defense. This Part outlines the features of the current crisis in public defense and explains how the lack of resources lead public defenders to pressure clients to take deals offered by prosecutors. Part IV introduces the problem of the innocent indigent defendant and explains why attorneys' incentives to pressure clients to take deals can result in bad choices. Part V provides a closer look at how lawyers' biases lead them to favor deals and how courts nevertheless routinely privilege attorney choice. Part VI proposes an alternative model, one in which the criminal defendant himself plays a dominant role in every major step in the criminal defense process. This Part reveals a number of advantages to a defendant-led defense, and provides a data-driven rationale for why the defendant, and not the attorney, should be in control of the decision process.

\section{BIASES THAT INFLUENCE CRIMINAL DEFENSE ATTORNEYS}

\section{A. Biases Stemming from Repeat Experience with the Criminal Justice System}

Prosecutors and public defenders operate in a system in which plea agreements dominate the landscape. ${ }^{21}$ The fact that a steady stream of

\footnotetext{
20. See M. Somjen Frazer, The Impact of the Community Court Model on Defendant Perceptions of Fairness, CTR. FOR CT. INNOVATION 14-20 (2006), http://www.courtinnovation.org/sites/default/files/Procedural_Fairness.pdf.

21. See lindsey Devers, Bureau Just. Assistance, Plea and Charge Bargaining: $\begin{array}{llll}\text { RESEARCH } & \text { SUMMARY } & \text { (2011), }\end{array}$
} 
criminal defendants accept plea deals perpetuates the notion that mostif not all — defendants are guilty. Proponents of the status quo generally assume that criminal defendants who accept plea agreements are guilty of criminal acts. In fact, in order to maintain the belief in their own professionally ethicality, defense attorneys must subscribe to this belief. As a result of functioning in the current system, expectations about the guilt of criminal defendants is reinforced and perpetuated; virtually all criminal defendants begin to appear guilty of the charged crimes. Moreover, because defense attorneys are obliged to obtain for her client the best outcome possible, the attorney must also believe that plea bargains are optimal for her clients in almost all cases. These assumptions have important implications for how a defense attorney makes judgments about her client and the actions that she takes in her role as counsel for that client.

\section{Priming}

Priming describes a situation in which early exposure to a concept, idea or belief sensitizes the subject to a later presentation of the same or a similar target. $^{22}$ By virtue of experience, defense attorneys - particularly those who have been in the system for a long period of time-are primed to expect (a) that their clients are guilty and (b) that the best outcome is a plea bargain. Priming a concept influences later acceptance for similar concepts by sensitizing cognitive and affective reactions to subsequent targets. $^{23}$ Priming works because early exposure activates certain knowledge structures, which, in turn, influence individuals' interpretation of later events or issues. ${ }^{24}$ The accessibility of a particular

https://www.bja.gov/Publications/PleaBargainingResearchSummary.pdf; Matthew Clarke, Dramatic Increase in Percentage of Criminal Cases Being Plea Bargained, Prison Legal News (Jan. 15, 2013), https://www.prisonlegalnews.org/news/2013/jan/15/dramatic-increase-in-percentage-ofcriminal-cases-being-plea-bargained.

22. See Robert B. Cialdini et al., A Focus Theory of Normative Conduct: Recycling the Concept of Norms to Reduce Littering in Public Places, 58 J. Personality \& Soc. Psychol. 1015, 1023 (1990) (citations omitted) ("Most, although not all, explanations of priming effects incorporate the notion of spreading activation, which posits that similar concepts are linked together in memory within a network of nodes and that activation of one concept results in the spreading of the activation along the network to other related concepts.").

23. Sheila T. Murphy \& R. B. Zajonc, Affect, Cognition, and Awareness: Affective Priming with Optimal and Suboptimal Stimulus Exposures, 64 J. Personality \& Soc. Psychol. 723, 734, 736 (1993) (finding that millisecond-long encounters with negative or positive stimuli can produce non-specific emotional reactions to unrelated stimuli).

24. See generally Robert S. Wyer \& Thomas K. Srull, Category Accessibility: Some Theoretical and Empirical Issues Concerning the Processing of Social Stimulus Information, in Social Cognition: THE ONTARIO Symposium 161-197 (E. Tory Higgins et al. eds., 1981). 
concept - the ease with which the concept is retrieved and used-is enhanced by prior exposure to the concept. ${ }^{25}$ Priming has been demonstrated in a wide variety of contexts. For example, experimenters have been able to prime morality and increase ethical behavior by asking people to recall the Ten Commandments. ${ }^{26}$ Priming is a technique commonly used by lawmakers to influence members of the public. ${ }^{27}$

Priming is powerful because mere exposure to one thing can change emotions about, interpretations of, and even memories of specific phenomena. ${ }^{28}$ The experience that serves as a prime will later be more influential and more important. The priming effect increases with the number of times the knowledge category is activated. ${ }^{29}$ Priming can make a certain idea seem so correct that an individual will disregard information that contradicts the notion that was primed. ${ }^{30}$

After repeatedly observing criminal defendants admit guilt and accept punishment, the concept of the guilty defendant becomes perennially primed. This can make the cognitive link between criminal defendant and guilt pervasive, lasting, and powerful. The tendency to start out with a presupposition of guilt influences attorneys' subsequent judgments about the character of the defendant, his past acts, the

25. Youjae Yi, The Effects of Contextual Priming in Print Advertisements, 17 J. CONSUMER RES. 215, 216 (1990); see also Tory E. Higgins \& Gillian A. King, Accessibility of Social Constructs: Information Processing Consequences of Individual and Contextual Variability, in Personality, COGnition, AND Social InTERACTION 69-122 (Nancy Cantor \& John F. Kihlstrom eds., 1981).

26. Nina Mazar, On Amir \& Dan Ariely, The Dishonesty of Honest People: A Theory of SelfConcept Maintenance, 45 J. MARKETING RES. 633, 635-37 (2008) (finding that people acted more ethically after being prompted to think of honor codes and the Ten Commandments).

27. See Dietram A. Scheufele \& David Tewksbury, Framing, Agenda Setting, and Priming: The Evolution of Three Media Effects Models, 57 J. CoMM. 9, 9-11 (2007) (citation omitted) ("The 1980 s and early 1990s ... brought the most recent stage of political-effects research. Sometimes labeled 'negation models,' approaches like priming and framing were based on the idea that mass media had potentially strong attitudinal effects ....").

28. "[I]f we are primed to think about baseball, we are more likely to remember seeing a baseball on a table even if the table is crowded with many different objects of which the baseball is only one." Kathryn M. Stanchi, The Power of Priming in Legal Advocacy: Using the Science of First Impressions to Persuade the Reader, 89 OR. L. REV. 305, 306 (2010).

29. Thomas K. Srull \& Robert S. Wyer, Jr., The Role of Category Accessibility in the Interpretation of Information About Persons: Some Determinants and Implications, $37 \mathrm{~J}$. PERSONALITY \& SOC. PSYCHOL. 1660, 1661-62 (1979) (noting that, once a trait or schema is made more accessible by previous cognitive activity, the likelihood that the schema will be used to encode new information is increased).

30. See Daniel G. Linz \& Steven Penrod, Increasing Attorney Persuasiveness in the Courtroom, 8 LAW \& PsYCHOL. REV. 1, 9-10 (1984); see also Donald C. Langevoort, Organized Illusions: A Behavioral Theory of Why Corporations Mislead Stock Market Investors (and Cause Other Social Harms), in BeHAVIORAL LAW \& ECONOMICS 144, 147-48 (Cass R. Sunstein ed., 2000) (discussing how people tend to be biased against revising their opinions). 
evidence, and the wisdom of accepting a plea deal. Priming is also closely linked with anchoring, belief perseverance, and a number of other biases discussed below.

\section{Anchoring}

Research has shown that, when faced with a task, people are heavily influenced by information they receive early in the process. As priming research suggests, that which comes first is given special emphasis. For example, when people are provided an initial value, they tend to "anchor" on that value and adjust away from it. ${ }^{31}$ This is true even when that initial value is arbitrary, or even outrageous. In an experiment in which business school students were asked to negotiate to purchase a company, researchers found a 5.1 million dollar difference in final purchase price, depending upon whether the buyer or the seller proposed the initial price. ${ }^{32}$ Although the students arrived at an agreement, the party who proposed the opening bid did best; if the buyers made an offer first, they were able to buy the company for far less than when the seller set the initial price. ${ }^{33}$

In a standard business transaction, either party might start the negotiation. However, in the criminal context, the first offer usually originates with the prosecutor. Furthermore, a savvy prosecutor develops standard negotiation tactics that make her desired result more likely; often a prosecutor's strategic approach involves use of an anchor value. $^{34}$ In other words, prosecutors routinely exploit this bias and

31. Adam D. Galinsky \& Thomas Mussweiler, First Offers as Anchors: The Role of Perspective-Taking and Negotiator Focus, 81 J. Personality \& Soc. Psychol. 657, 660 (2001) [hereinafter First Offers as Anchors]; see also Amos Tversky \& Daniel Kahneman, Judgment Under Uncertainty: Heuristics and Biases, 185 SCI. 1124, 1128 (1974) (explaining the anchoring effect).

32. First Offers as Anchors, supra note 31, at 660-61.

33. When seller-students made the opening offer, they first offered to sell the plant for an average of $\$ 26.6$ million, and the average final purchase price was $\$ 24.8$ million. Id. at 661 . When buyer-students made the initial offer, they first offered to buy the plant for an average of $\$ 16.5$ million, and the average final purchase price was $\$ 19.7$ million. Id. The difference between final purchase price (depending upon who set the initial offer) was $\$ 5.1$ million dollars. Id.

34. Stephan Bibas describes this scenario:

For example, a prosecutor might initially offer a robbery defendant twenty years' imprisonment by piling on every plausible enhancement. The defendant, of course, rejects this unreasonable offer out of hand, but the initial offer serves as a high anchor.... By the time the prosecutor comes down to twelve years, the defendant is ready to jump at the deal. If the prosecutor had started out at twelve years, however, the defendant might have anchored on that number as the highest likely sentence and rejected it as a bad deal.

Stephanos Bibas, Plea Bargaining Outside the Shadow of Trial, 117 HARV. L. Rev. 2463, 2517-18 (2004) [hereinafter Shadow of Trial]. 
perceive the results of these negotiations as fair, in large part because of the self-serving bias (discussed below). ${ }^{35}$ Distortions caused by anchoring are particularly worrisome, given the structure of plea negotiations and the large percentage of cases resulting in plea deals. ${ }^{36}$

\section{Belief Perseverance}

The priming and anchoring effects both describe the way that early information can distort later decision-making. The tendency for earlyformed impressions to last and last, even when disconfirming information is provided, has been dubbed "belief perseverance." "37 Researchers have found that participants who are provided false feedback on a task maintain initial impressions of performance even after having been told that the feedback was bogus. ${ }^{38}$ In one study on perceptions of personality traits and professions, people who were led to believe that there was a negative or positive association between risk preferences and firefighting ability adhered to this belief, even when the information was discredited. ${ }^{39}$

Belief perseverance is pervasive and powerful, as has been demonstrated in studies on prosecutors' assessments of guilt. Real-life manifestations of this bias occur when prosecutors refuse to accept the validity of irrefutable exculpatory evidence post-conviction. ${ }^{40}$ In less

35. Linda Babcock et al., Biased Judgments of Fairness in Bargaining, 85 AM. ECON. REV. 1337, 1338 (1995) (pointing out that parties on opposite sides perceive their own offers as fair).

36. Crushing caseloads have led to a "plea bargain assembly line" in many states. Laura I. Appleman, The Plea Jury, 85 InD. L.J. 731 , 769 (2010); Colin Miller, Anchors Away: Why the Anchoring Effect Suggests That Judges Should Be Able to Participate in Plea Discussions, 54 B.C. L. REV. 1667, 1688-89 (2013) [hereinafter Anchors Away].

37. Craig A. Anderson \& Kathryn L. Kellam, Belief Perseverance, Biased Assimilation, and Covariation Detection: The Effects of Hypothetical Social Theories and New Data, 18 PERSONALITY \& Soc. Psychol. Bull. 555, 555, 557 (1992); see also Lee Ross, Mark R. Lepper \& Michael Hubbard, Perseverance in Self-Perception and Social Perception: Biased Attributional Processes in the Debriefing Paradigm, 32 J. PERSONALITY \& SOC. PSYCHOL. 880, 880, 891 (1975) [hereinafter Perseverance in Self-Perception and Social Perception].

38. Perseverance in Self-Perception and Social Perception, supra note 37, at 882-84 (noting that, even after having been shown the experiment materials that randomly assigned participants to various feedback conditions, people continued to exhibit beliefs consistent with the original, false feedback).

39. Craig A. Anderson, Mark R. Lepper \& Lee Ross, Perseverance of Social Theories: The Role of Explanation in the Persistence of Discredited Information, 39 J. PERSONALITY \& SoC. PSYCHOL. 1037, 1039-40 (1980).

40. One example is the case of Robert Lee Stinson, whose conviction was rendered suspect when DNA testing revealed that the bite mark from the victim was not Stinson's. Assistant District Attorney Norman Gahn refused to retry Stinson, but asserted that no factual evidence implied Stinson's innocence. Tom Kertscher, Prosecutors Won't Retry Innocence Project Case, MILWAUKEE J. SENTINEL (July 27, 2009), http://archive.jsonline.com/news/milwaukee/51793602.html. 
starkly obvious cases, attorneys on both sides can be influenced by initial impressions. The simple fact that a criminal defendant has been charged and indicted can imply guilt, and research demonstrating that early judgments can be sticky and resistant to modification has been demonstrated in numerous studies. ${ }^{41}$ When a defendant has confessed, even the most diligent defense counsel may give up any notion of innocence. This is true-as behavioral science demonstrates-even when there are good reasons to believe that the confession may have been coerced. ${ }^{42}$ As discussed later in this Article, jurors are significantly more likely to convict a defendant who has confessed, even when there is good reason to suspect the validity of the confession. ${ }^{43}$ A criminal justice insider, such as a prosecutor or defense attorney, may be particularly unlikely to deviate from an initial judgment. Research has shown that experts are particularly confident in the veracity of their own judgments and are resistant to change. ${ }^{44}$

\section{B. Biases Relating to Confirming Existing Beliefs}

Closely linked to belief perseverance, another set of biases relates to a tendency for individuals to cling to initial attitudes. The biases discussed below explain how lingering judgments can influence how people react to novel information, as well as whether individuals are likely to search out and interpret new evidence. Response sets, response bias, anchoring, belief perseverance and other biases can cause individuals to incorrectly interpret future situations based upon their knowledge or beliefs from past outcomes or experience. It is therefore unlikely that even the most devoted public defender will genuinely evaluate the likelihood of guilt or innocence from a "fresh perspective" with each new client. This is particularly true when a new client has an

41. See Martin F. Davies, Belief Persistence After Evidential Discrediting: The Impact of Generated Versus Provided Explanations on the Likelihood of Discredited Outcomes, $33 \mathrm{~J}$. EXPERIMENTAL SOC. PSYCHOL. 561, 562 (1997); Craig A. Anderson, Abstract and Concrete Data in the Perseverance of Social Theories: When Weak Data Lead to Unshakeable Beliefs, 19 J. EXPERIMENTAL SOC. PSYCHOL. 93, 95 (1983); Hollyn M. Johnson \& Colleen M. Seifert, Sources of the Continued Influence Effect: When Misinformation in Memory Affects Later Influences, $20 \mathrm{~J}$. EXPERIMENTAL PSYCHOL.: LEARNING, MEMORY \& COGNITION 1420, 1432 (1994).

42. See infra notes $158-61$ and accompanying text.

43. Saul M. Kassin \& Holly Sukel, Coerced Confessions and the Jury: An Experimental Test of the "Harmless Error" Rule, 21 LAW \& HUM. BEHAV. 27, 27-46 (1997).

44. Andrea O. Baumann et al., Overconfidence Among Physicians and Nurses: The 'MicroCertainty, Macro-Uncertainty' Phenomenon, 32 SOC. SCI. \& MED. 167 (1991). For discussion on over-confidence bias, see also William A. Edmundson, Contextualist Answers to Skepticism, and What a Lawyer Cannot Know, 30 FLA. ST. U. L. REV. 1, 14 (2002) ("I do not for a moment deny that criminal-defense lawyers routinely form the belief that their clients are guilty."). 
old record. Past criminal acts can prime the defense attorney to think about past clients with similar records, and can render those clients cognitively available. This phenomenon is likely to occur even for attorneys who aspire to represent their clients zealously.

\section{Confirmation Bias}

The confirmation bias has received a great deal of attention in the criminal justice literature - particularly from scholars trying to explain the phenomenon of wrongful convictions. Many commentators have written about the tendency of prosecutors to hone in on a particular person of interest, selectively seeking out evidence that tends to implicate that person, and failing to see holes in the case against him. ${ }^{45}$ Less focus has been placed upon the potential for this bias to influence the defendant's own counsel. However, as one scholar puts it, "[i]dentity-based prejudices, particularly racial bias, often trigger confirmation bias ...." ${ }^{, 46}$ Differences in socio-economic background, education, and race can influence even diligent defense attorneys powerfully, and without the attorneys being conscious of them. ${ }^{47}$ Implicit biases trigger initial expectations, and later evidence is interpreted to be consistent with these early attitudes. Saul Kassin and

45. Examples of works on this topic include: Alafair S. Burke, Prosecutorial Passion, Cognitive Bias, and Plea Bargaining, 91 MARQ. L. REV. 183 (2007) [hereinafter Prosecutorial Passion]; Alafair Burke, Neutralizing Cognitive Bias: An Invitation to Prosecutors, 2 NYU J. L. \& LIBERTY 512 (2007) [hereinafter An Invitation to Prosecutors]; Barbara O'Brien, A Recipe for Bias: An Empirical Look at the Interplay Between Institutional Incentives and Bounded Rationality in Prosecutorial Decision Making, 74 Mo. L. REV. 999 (2009); Rachel E. Barkow, Prosecutorial Administration: Prosecutor Bias and the Department of Justice, 99 VA. L. REV. 271 (2013); and DAVID A. HARRIS, FAILED EVIDENCE: WHY LAW ENFORCEMENT RESISTS SCIENCE (2012) (exploring the question of why investigators and prosecutors resist the application of social science findings to their work).

46. Simon Stern, Constructive Knowledge, Probable Cause, and Administrative Decisionmaking, 82 Notre DAME L. REV. 1085, 1121 (2007) ("At its most serious, such bias results in strained interpretations of the available evidence and failure to take note of evidence that erodes belief in the suspect's guilt, incriminates someone else, or is simply unaccountable under the preferred explanation."). For other discussions of race and the confirmation bias, see Sheri Lynn Johnson, Race and the Decision to Detain a Suspect, 93 YALE L.J. 214 (1983); Tracey Maclin, Race and the Fourth Amendment, 51 VAND. L. REV. 333, 387 (1998); David Rudovsky, Law Enforcement by Stereotypes and Serendipity: Racial Profiling and Stops and Searches Without Cause, 3 U. PA. J. CONST. L. 296 (2001).

47. See L. Song Richardson \& Phillip Atiba Goff, Implicit Racial Bias in Public Defender Triage, 122 YALE L.J. 2626, 2636 (2013) (arguing that "[w]hen translated to the context of [public defender] triage, these studies suggest that when clients are black or otherwise criminally stereotyped, [implicit biases] can influence evidence evaluation, potentially causing [public defenders] to unintentionally interpret information as more probative of guilt. Consequently, [public defenders] may determine that the state will have little difficulty meeting its burden of proof and thus, that the case does not warrant much effort."). 
others have more recently discussed how, when evidence in a case is related, confessions may also result in "a chain of confirmation biases" that affect investigators, perceptions of other evidence in the case, and post-conviction review. ${ }^{48}$

Certain features of a defendant's case or situation-such as the existence of an eyewitness identification or a confession - form the basis for a belief that is substantiated by future interpretations of ambiguous evidence. Kassin coined the term "corroboration inflation" 49 to describe how independent pieces of evidence can seem to accumulate and appear supportive of initial beliefs. Researchers have shown how forensic analysis can be tainted by the confirmation bias in a variety of ways. In the course of an investigation the way a defendant is interviewed can infect his responses, and increase the chance that the information gleaned from the interview will appear to support early conclusions. In one study, researchers ${ }^{50}$ found that the expectations of polygraph examiners influence how they conduct their interviews as well as what conclusions they draw from the test results.

Because public defenders are repeat players in a criminal justice system stocked with defendants who overwhelmingly plead guilty, the "guilty" defendant is an anchor. Limited time and resources increase the chance that a public defender will use heuristics - rules of thumb-in making decisions about how to triage cases. ${ }^{51}$ Confirmation bias suggests that when a defendant has confessed, or there is other impactful evidence of guilt, a lawyer is unlikely to see discrepancies between other evidence and that original incriminating evidence. The human mind, which strives to find sense in the world, will attempt to make a whole of the parts, leading to unconscious assumptions about how the pieces fit together.

48. Saul M. Kassin, Why Confessions Trump Innocence, 67 Am. Psychologist 431, 441 (2012) (stating that "false confessions, once taken, arouse a strong inference of guilt, thereby unleashing a chain of confirmation biases that make the consequences difficult to overcome despite innocence.").

49. Id. at 440-41; see also Saul M. Kassin, The Psychology of Confession Evidence, 52 AM. Psychologist 221, 221-33 (1997); Saul M. Kassin et al., Police-Induced Confessions: Risk Factors and Recommendations, 34 LAW \& HuM. BEHAV. 3 (2010).

50. Eitan Elaad et al., The Effects of Prior Expectations and Outcome Knowledge on Polygraph Examiners' Decisions, 7 J. Behav. DeCISION MAKING 279, 279-90 (1994).

51. The use of cognitive heuristics is an unconscious and generally adaptive process. All human beings use heuristics to navigate the world. Without rough-and-ready rules about how to behave, we would be paralyzed by the vast number of choices and pieces of information we had to manage. See generally Gerd Gigerenzer et AL., Simple Heuristics that Make Us SMART (1999). 
Confirmation biases can also be fueled by motivational goals. ${ }^{52}$ According to researcher Ziva Kunda, motivated reasoning occurs in the context of two types of goals: accuracy goals and directional goals. ${ }^{53}$ The first relates to the need human beings have to be accurate in their judgments. $^{54}$ The second is relevant anytime individuals seek a particular desired conclusion. ${ }^{55}$ Kunda argues that in order to avoid psychic discomfort, decision-makers maintain an "illusion of objectivity" that prevents them from recognizing that their cognition has been tainted by preference or desire. ${ }^{56}$

In the instances where a client has confessed, motivational confirmation biases and a lack of resources can create a perfect storm. A defense attorney who is faced with a client's confession may well conclude, first, that his client committed the crime and, second, that the case is for all practical purposes hopeless. Faced with limited time and a backlog of cases, the attorney will urge the defendant to take a plea deal. The attorney may develop negative feelings toward a confessing client, experiencing frustration at the state of the case. She may feel that the client is foolish or impulsive. If the defendant recants the confession, the attorney may come to believe that the client is lying to her.

\section{Tunnel Vision}

The confirmation bias can lead defense attorneys to take a narrow view of their client's situation. In evaluating facts, the pervasive tendency to see new evidence as supportive of existing beliefs can also result in an unconscious blindness to potentially contradictory information, creating a kind of tunnel effect. ${ }^{57}$ A related concept in the psychological literature is "selective information processing," which occurs when an individual overvalues information that supports a preexisting belief and undervalues evidence that contradicts that belief. ${ }^{58}$ Several articles have discussed situations wherein police or prosecutors have focused an investigation on an individual or group of individuals and have viewed all evidence as increasingly suggestive of guilt for the

\footnotetext{
52. See infra notes 53-56 and accompanying text.

53. Ziva Kunda, The Case for Motivated Reasoning, 108 PsYCHOL. BULL. 480, 483 (1990).

54. Id.

55. $I d$.

56. Id.

57. Keith A. Findley \& Michael S. Scott, The Multiple Dimensions of Tunnel Vision in Criminal Cases, 2006 Wis. L. ReV. 291, 316-17 (2006).

58. An Invitation to Prosecutors, supra note 45, at 517-18.
} 
identified party or parties. ${ }^{59}$ Eventually these individuals were cleared, but only when overwhelming evidence of innocence made their innocence incontrovertible. ${ }^{60}$

\section{Motivational Biases}

The term "motivational bias" refers to more than specific exogenous factors that may motivate defense attorneys to steer their clients toward a guilty plea. ${ }^{61}$ In psychology, a "motivational" factor refers to any innate belief or behavior as self-protective. Examples are those that protect one's ego or prevent one from feeling emotional pain or psychic discomfort. $^{62}$ Each of the following biases can be understood from the perspective of the individual maintaining a positive outlook and selfevaluation.

\section{Overconfidence Bias}

Most human beings are overly confident in their own abilities and knowledge. $^{63}$ David Dunning and colleagues hypothesized that the reason for consistent overconfidence in judgments of others is that individuals fail to account for the uncertainty of situational variables when making predictions, and therefore they do not make the appropriate downward adjustment to their confidence. ${ }^{64}$ A particularly robust area for overconfidence is in individuals' judgments about other human beings. ${ }^{65}$ More than half a decade of research has shown that

59. Susan Bandes, Loyalty to One's Convictions: The Prosecutor and Tunnel Vision, 49 How. L.J. 475, 479-480 (2006).

60. Id. at $476-80$

61. See infra notes 71-75 and accompanying text; see also Prescriptions for Ethical Blindness, supra note 4, at 357.

62. Denial is a commonly referenced example in clinical psychology. This was one of a number of "defense mechanisms" first identified by Sigmund Freud. See AnNa Freud, THE Ego and the Mechanisms of Defense (1937); Sigmund Freud, The Neuro-Psychoses of DefEnCE [sic] 41-61 (1894).

63. Stephen V. Burks et al., Overconfidence and Social Signalling, 80 REV. ECON. STUD. 949, 950 (2013). The multidimensionality of overconfidence has been described as "(1) overestimation of one's actual performance, (2) overplacement of one's performance relative to others, and (3) excessive precision in one's beliefs." Don A. Moore \& Paul J. Healy, The Trouble with Overconfidence, 115 PSYCHOL. REV. 502, 502 (2008).

64. David Dunning et al., The Overconfidence Effect in Social Prediction, 58 J. PERSONALITY \& SOC. PSYCHOL. 568 (1990).

65. Id. at 568, 572 (Subjects were asked to predict the response of a target to various situations. The level of familiarity with the target was manipulated. Subjects gave overconfident estimates in more than $80 \%$ of all predictions across levels of familiarity.). See also Dale W. Griffin et al., The Role of Construal Processes in Overconfident Predictions About the Self and Others, $59 \mathrm{~J}$. 
professionals routinely overestimate their own ability to make accurate judgments about others. ${ }^{66}$ This is true even when the professionals are psychologists, who presumably have particular insight into human judgment and choice. ${ }^{67}$ Lawyers, no less than psychologists and individuals in other professional roles, have exhibited excessive confidence in their own ability to predict legal outcomes. ${ }^{68}$

Overestimating one's own accuracy in discerning the motivations and actions of criminal defendants has far-reaching implications. Other biases, such as priming, anchoring, and belief perseverance set the public defender's early expectations, and the confirmation bias serves to reinforce these beliefs. Defense counsel is generally the only voice for the defendant in the criminal justice process; ${ }^{69}$ the extent to which her mind is open to exculpating information and alternative theories of the case, the more likely the innocent defendant will be to get the advocacy he needs. Overconfidence bias makes the defense attorney less likely to question her own expectations. It may make it less likely that she will reexamine her belief that her client is guilty following an eyewitness identification or the defendant's confession, even when faced with information that could undermine her assumptions. ${ }^{70}$

\section{Self-Serving Bias}

Self-serving bias is a tendency to interpret events in a way that is advantageous to oneself. ${ }^{71}$ When making judgments about what is right, correct, or fair, individuals tend to do so with reference to that which is personally flattering. ${ }^{72}$ In some cases, idiosyncratic views impacting

PERSONALITY \& SOC. PSYCHOL. 1128, 1129 (1990).

66. Stuart Oskamp, Overconfidence in Case-Study Judgments, 29 J. Consulting PsYCHOL. 261, 261-65 (1965).

67. $I d$.

68. Jane Goodman-Delahunty et al., Insightful or Wishful: Lawyers' Ability to Predict Case Outcomes, 16 PSYCHOL., PUB. POL'Y \& L. 133, 133 (2010) (finding that "lawyers were overconfident in their predictions.... Female lawyers were slightly better calibrated than their male counterparts and showed evidence of less overconfidence.").

69. See infra Part V.

70. Overconfidence may also infect first-time criminal defendants when they are interacting with their lawyers. Bibas argues that "[n] eophytes have plenty of room to be overconfident because they are unfamiliar with the justice system, whereas recidivists' knowledge and experiences may limit their overconfidence." Shadow of Trial, supra note 34, at 2502.

71. Russell Korobkin \& Chris Guthrie, Symposium, Heuristics and Biases at the Bargaining Table, 87 MARQ. L. REV. 795, 800-01 (2004).

72. Ward Farnsworth, The Legal Regulation of Self-Serving Bias, 37 U.C. DAVIS L. REV. 567, 572 (2003) ("A claim that a judgment about fairness is self-serving typically is a counterfactual about a value judgment: [you] would not be arguing that outcome $\mathrm{X}$ is fair if it were not 
only the decision-maker cause no exogenous harm. ${ }^{73}$ However, where the decision-maker's interests diverge from other stakeholders, the selfserving bias becomes problematic. Take, for example, the case of the politician who perceives that she is more likely to be reelected if she votes for a bill supported by wealthy interests. Suppose that this bill creates tax loopholes for the wealthy interests, leaving poorer constituents to pick up associated costs. The politician may adopt a selfserving view of the bill-minimizing the negative impact to the community - in order to feel comfortable voting for it. ${ }^{74}$ Similarly, a defense attorney is overburdened with cases, often believes that her client is guilty, and generally wants to stay on good terms with her prosecutor-colleague. $^{75}$ These interests support advising her client to accept a plea deal. In order to arrive at the conclusion that she can and should proffer this advice, she might look more favorably on a plea deal than she would if their interests were not relevant.

\section{Bias Blindspot}

The various biases discussed above may interfere with a wellmeaning and otherwise ethical attorney's ability to serve her client's interest with a clear head. Not surprisingly, research on biases has revealed that we have trouble perceiving our own biases. ${ }^{76}$ This difficulty is called "bias blind spot."77 Emily Pronin, the psychologist who coined the term bias blind spot conducted a series of studies examining how individuals evaluated themselves and others with respect

advantageous to [you], or if [you] did not have a stake in the resolution of the dispute.").

73. Ward Farnsworth provides this example, "If Fred thinks the world is flat and so will not travel more than a hundred miles from his home, this can be regretted because presumably he would prefer to be well informed and not to labor under misconceptions that limit his freedom of movement. If he won't travel because he dislikes traveling, that's different." Id. at 573.

74. Stephan Bibas points out that "the more information people have, the more room there is for bias." Shadow of Trial, supra note 34, at 2498. Empirical research has shown that when participants receive new information about the death penalty, both death penalty supporters and death penalty opponents interpret the same ambiguous evidence as supportive of their own preferred view. See Charles G. Lord et al., Biased Assimilation and Attitude Polarization: The Effects of Prior Theories on Subsequently Considered Evidence, 37 J. Personality \& Soc. Psychol. 2098, 2105, 2107-08 (1979). Problematically, indigent defendants often lack access to information, and so are less likely to adopt a self-serving bias at a time when this bias might spur them to reject a quick plea offer in favor of more process and evidence gathering.

75. See infra note 116-17 and accompanying text (discussing some of the pressures facing public defenders).

76. See Emily Pronin \& Matthew B. Kugler, Valuing Thoughts, Ignoring Behavior: The Introspection Illusion as a Source of the Bias Blind Spot, 43 J. EXPERIMENTAL SOC. PSYCHOL. 565 (2007).

77. Id. at 565 . 
to biased attitudes. ${ }^{78}$ Pronin and her colleagues found that participants rated themselves to be less biased than others. ${ }^{79}$ Moreover, these participants held fast to previous judgments even after receiving education about how they could have been biased. ${ }^{80}$ Meanwhile, participants were quick to identify others' self-serving attributions as skewed. ${ }^{81}$ When it comes to lawyers, much has been written about the tendency of members of the profession to exhibit overconfidence in a host of situations. ${ }^{82}$ This seemingly unflappable self-assurance may exacerbate the tendency of attorneys to migrate through decision processes without awareness of unconscious biases that are affecting strategic choices they help their clients make.

\section{Behavioral Ethics \& Ethical Blindness}

Behavioral ethics is a nascent field in which behavioral science is applied to explain why people behave in unethical ways. ${ }^{83}$ Several scholars, including Robert Prentice, Tigran Eldred, Jennifer Robbennolt, and Jean Sternlight, among others, have written about the tendency of certain actors to be "blind" to their own unethical practices and behaviors. $^{84}$ Attorneys are regulated by rules of professional conduct

78. Id.; Emily Pronin et al., The Bias Blind Spot: Perceptions of Bias in Self Versus Others, 28 PERS. \& SOC. PSYCH. BuLL. 369 (2002) [hereinafter Bias Blind Spot].

79. Bias Blind Spot, supra note 78, at 369-70.

80. Id. at $374-76$.

81. Id. at 376-78.

82. See, e.g., Elizabeth F. Loftus \& Willem A. Wagenaar, Lawyers' Predictions of Success, 28 JURIMETRICS J. 437, 442-50 (1988) (discussing studies demonstrating lawyer overconfidence in criminal and civil litigation); see also Moore \& Healy, supra note 63 (noting overconfidence as an explanation for litigation).

83. Max H. Bazerman \& Francesca Gino, Behavioral Ethics: Toward a Deeper Understanding of Moral Judgment and Dishonesty, 8 ANN. REV. L. \& SoC. SCI. 85, 85 (2012) ("By focusing on a descriptive rather than a normative approach to ethics, behavioral ethics is better suited than traditional approaches to addressing the increasing demand from society for a deeper understanding of what causes even good people to cross ethical boundaries.").

84. Prescriptions for Ethical Blindness, supra note 4, at 369 ("[B] ehavioral ethics suggests an alternative explanation, one that is more consistent with the available research ... [that] lawyers are susceptible to the forces that produce ethical blindness, which create a false experience of meeting professional duties, even in the face of clear evidence to the contrary."); Robert A. Prentice, Behavioral Ethics: Can It Help Lawyers (and Others) Be Their Best Selves?, 29 NOTRE DAME J.L. ETHICS \& PUB. POL'Y 35, 36 (2015) (describing behavioral ethics as "primarily descriptive, rather than normative, explaining how cognitive heuristics, psychological tendencies, social and organizational pressures, and even seemingly irrelevant situational factors can make it more likely that good people will do bad things."); Jennifer K. Robbennolt \& Jean R. Sternlight, Behavioral Legal Ethics, 45 ARIZ. ST. L.J. 1107, 1114 (2013) [hereinafter Behavioral Legal Ethics] (quoting MAX H. BAZERMAN \& DON A. MOORE, JudgMent IN MANAGERIAL DECISION MAKING 123 (7th ed. 2008)) ("Ethical lapses occur more easily and less intentionally than we might imagine. While most of us desire to act ethically, "psychological processes... [can] lead people to engage in ethically 
that are stricter and more comprehensive than most other professions. ${ }^{85}$ Each American jurisdiction has adopted its own rules, which typically include conflicts of interest, confidentiality, advising, advertising, billing, trust funds, and illicit relations with clients. ${ }^{86}$ However, rules at the national and state level are necessarily flexible, and so, are nebulous. As Robbennolt and Sternlight point out, "[w]hile abundant, the ethical rules governing attorneys leave many gaps, and can be ambiguous and even conflicting. ${ }^{87}$ In fact, the model rules themselves contain language that acknowledges the tension "between a lawyer's responsibilities to clients, to the legal system and to the lawyer's own interest in remaining an ethical person while earning a satisfactory living." ${ }^{\prime 8}$ Together, the bias blind spot and ethical blindness phenomena suggest that defense lawyers fail to identify their own proclivity to favor a guilty plea. Moreover, to the extent that a client has characteristics in common with other clients who have pled guilty, a public defender may implicitly presume guilt. These factors may help to explain findings that lawyers appointed to represent indigent clients do not take necessary steps to defend their clients. According to one study, "appointed defense lawyers visited crime scenes and interviewed witnesses in only 4 percent of their cases, and used experts in only 2 percent," 89 leading to the conclusion that "[u]nderpaid, overburdened defense counsel have incentives to minimize the time spent on individual cases ...."90

questionable behaviors that are inconsistent with their own preferred ethics."'); see also Guido Palazzo et al., Ethical Blindness, 109 J. Bus. ETHICs 323, 323-38 (2012) (arguing that ethical blindness, when people "behave unethically without being aware of it," occurs as an interaction between "sensemaking" and "context factors").

85. Model Rules of Professional Conduct: About the Model Rules, AM. BAR Ass'N, http://www.americanbar.org/groups/professional_responsibility/publications/model_rules_of_profes sional_conduct.html (last visited Oct. 8, 2016) ("The ABA Model Rules of Professional Conduct were adopted by the ABA House of Delegates in 1983. They serve as models for the ethics rules of most states. Before the adoption of the Model Rules, the ABA model was the $1969 \mathrm{Model}$ Code of Professional Responsibility. Preceding the Model Code were the 1908 Canons of Professional Ethics (last amended in 1963).").

86. See, e.g., Mo. Rules OF PROF'L CONDUCT r. 4-2.1 (2007) ("In representing a client, a lawyer shall exercise independent professional judgment and render candid advice. In rendering advice, a lawyer may refer not only to law but to other considerations such as moral, economic, social, and political factors that may be relevant to the client's situation.").

87. Behavioral Legal Ethics, supra note 84, at 1125.

88. Id. (quoting MOdel Rules OF PROF'L CONDUCt, Prologue (2010)).

89. Andrew E. Taslitz, Wrongful Rights, 18 CRIM. JUST., Spring 2003, at 4, 10 (internal citation omitted) ("[J]udges prove frequently reluctant to free state funds to finance investigations for those whom the judges assume are guilty.").

90. Id. 


\section{OVERWHELMED LAWYERS AND HURRIED PLEAS}

The Supreme Court has held that defendants have a right to good representation at all critical stages, including the plea bargaining stage. ${ }^{91}$ But indigent defense representation is in crisis; public defenders have far less time and fewer resources than are necessary to provide their clients with decent representation. Under pressure to move cases through, defense lawyers are susceptible to cognitive biases, which influence their assessment of their clients' cases, and make them more likely to favor plea bargains. The result is a vicious cycle-fewer resources for defense lawyers mean more, and more rushed plea bargains. Meanwhile, plea bargaining takes place outside of the courtroom, so there is less oversight, which contributes to lawyering mistakes and results in fewer protections. Accordingly, under the very circumstances in which defendants are getting less complete representation than they deserve, the quick plea bargain contributes to the existing inadequacies. It is the perfect storm of under-representation for an underserved population.

\section{A. The Right to Effective Representation at the Plea Bargaining Stage}

The right of an indigent criminal defendant to competent counsel in all criminal cases was established more than forty years ago in the case of Gideon v. Wainwright. ${ }^{92}$ In Gideon, Justice Black, writing for a unanimous Court, held that the framers of the Constitution placed a high value upon the right of the accused to wage a proper defense and that all Courts in the land must respect that right. ${ }^{93}$ In the years following the Gideon opinion, the Court was left to decide the contours of that right; it grappled with the question of how effective that representation had to be in order to meet constitutional requirements. In Strickland v. Washington, ${ }^{94}$ more than twenty years after the holding in Gideon, the Court made clear that a defendant is entitled to more than pro forma representation and that; his counsel must be a "reasonably effective" advocate. ${ }^{95}$ However, Strickland's protection was far from robust.

91. Powell v. Alabama, 287 U.S. 45, 68-73 (1932); Missouri v. Frye, 132 S. Ct. 1399, 140708 (2012); Lafler v. Cooper, 132 S. Ct. 1376, 1387 (2012).

92. 372 U.S. 335 (1963). The right to counsel in federal criminal cases was codified in the Sixth Amendment to the United States Constitution (and affirmed in Johnson v. Zerbst, 304 U.S. 458, 462 (1938)), but it was not until Gideon that the Court incorporated this right by virtue of the Due Process clause of the Fourteenth Amendment. Gideon, 372 U.S. at 341-43.

93. Gideon, 372 U.S. at 345.

94. 466 U.S. 668 (1984).

95. Id. at 687. The Court ruled, however, that even where defense counsel was 
Defendants seeking relief under Strickland tended to be successful only in the case of actual conflicts of interest or egregious and catastrophic errors by counsel. ${ }^{96}$ So, for example, even in cases where a lawyer failed to seek potentially exculpatory DNA testing, only a quarter of defendants were granted a new trial. ${ }^{97}$ Lower courts have interpreted the right narrowly, as is clear from the Sixth Circuit's decision in Muniz v. Smith, ${ }^{98}$ holding that it was not ineffective assistance of counsel when Muniz's defense lawyer slept during the defendant's crossexamination. $^{99}$

In a companion case to Strickland, United States v. Cronic, ${ }^{100}$ the Court held that absence of counsel as a "critical stage" of the process entitles the defendant to a presumption of a constitutional violation. ${ }^{101}$ In 2002, in Bell v. Cone, ${ }^{102}$ the Court characterized a "critical stage" as one that "held significant consequences for the accused."103 Subsequent cases defined the plea bargaining process as one of those critical stages. In one such case, Hill v. Lockhart, ${ }^{104}$ the defendant pled guilty in state court to first-degree murder and theft of property. ${ }^{105}$ He subsequently sought federal habeas relief on grounds that his attorney had failed to advise him that he was required to serve one-half of his sentence before becoming eligible for parole. ${ }^{106}$ The United States Supreme Court held that the inmate's allegations were insufficient to establish grounds for

constitutionally inadequate, a trial verdict should only be reversed when counsel's errors materially prejudiced the outcome. Id. at 693-94.

96. Brandon L. Garrett, Validating the Right to Counsel, 70 WASH. \& LEE L. REV. 927, 928 (2013) [hereinafter Validating the Right to Counsel].

97. GARRETT, supra note 19, at 206-07. Garrett wrote, "One would think that those claims would be particularly straightforward ineffective assistance of counsel claims. However, judges held that the DNA would not have made a difference-of course it did, and when they later managed to obtain the DNA, it cleared them." Validating the Right to Counsel, supra note 96, at 946.

98. 647 F.3d 619 (6th Cir. 2011).

99. Id. at 624-25. In the course of the cross-examination, Muniz made statements that ultimately led to the admission of a State rebuttal witness as well as to the admission of a previously suppressed tape of a 911 call, both of which tended to incriminate Muniz. Id. at 624. Muniz was convicted of assault with intent to commit murder. Id. at 621.

100. 466 U.S. 648 (1984).

101. Id. at 659 n.25 ("The Court has uniformly found constitutional error without any showing of prejudice when counsel was either totally absent, or prevented from assisting the accused during a critical stage of the proceeding. See, e.g., Geders v. United States, 425 U.S. 80 (1976); Herring v. New York, 422 U.S. 853 (1975); Brooks v. Tennessee, 406 U.S. 605, 612-13 (1972); Hamilton v. Alabama, 368 U.S. 52, 55 (1961); White v. Maryland, 373 U.S. 59, 60 (1963) (per curiam); Ferguson v. Georgia, 365 U.S. 570 (1961); Williams v. Kaiser, 323 U.S. 471, 475-76 (1945).”).

102. 535 U.S. 685 (2002)

103. Id. at 695-96.

104. 474 U.S. 52 (1985).

105. Id. at 53 .

106. Id. 
habeas relief because, inter alia, he failed to argue that, had he been properly advised, he would have rejected the plea deal. ${ }^{107}$ In Padilla $v$. Kentucky, ${ }^{108}$ on the other hand, the Court held that a defendant had been denied effective assistance of counsel when counsel failed to adequately warn the defendant that one consequence of accepting the plea was deportation. ${ }^{109}$ A decade after Bell was decided, the Court reaffirmed the importance of a defendant's right to effective assistance of counsel during plea bargaining in Missouri v. Frye ${ }^{110}$ and Lafler v. Cooper. ${ }^{111}$ Unlike Hill and Padilla, Lafler and Frye involved situations in which the defendant failed to accept a plea deal offered by the prosecution. ${ }^{112}$ In Lafler, the Court acknowledged the central importance of the decision to accept a plea, noting that the criminal law system "is for the most part a system of pleas, not a system of trials."

\section{B. The Public Defense Crisis}

Although defendants are entitled to competent counsel for plea bargains, evidence suggests that, in large numbers, indigent defendants are not getting it. The demands of case overloads mean that public defenders are forced to make tough choices and spend far less time with clients than would otherwise be appropriate. In 2014, the current state of public defense was characterized by Attorney General Eric Holder as "unconscionable." "114 Comparisons of actual case workloads with recommended defense case workloads bring the problem into stark relief. In 1973, the National Advisory Council on Criminal Justice Standards and Goals (NAC) issued a report recommending yearly maximum caseloads for public defenders. Today, these maximum caseloads are likely unrealistic. ${ }^{15}$ Even so, the average public defender in the U.S.

\footnotetext{
107. Id. at $54,58-60$.

108. 559 U.S. $356(2010)$.

109. Id. at $373-75$.

110. 132 S. Ct. 1399, 1407-08 (2012).

111. 132 S. Ct. 1376, 1387 (2012).

112. In the case of Lafler, counsel erred with respect to interpretation of the criminal code, 132 S. Ct. at 1383, and in Frye, counsel failed to proffer the prosecutor's offer entirely, $132 \mathrm{~S}$. Ct. at 1404.

113. Lafler, 132 S. Ct. at 1388; see also Frye, 132 S. Ct. at 1407 (internal citations omitted) ("Ninety-seven percent of federal convictions and ninety-four percent of state convictions are the result of guilty pleas.").

114. Erik Eckholm, Public Defenders, Bolstered by a Work Analysis and Rulings, Push Back Against a Tide of Cases, N.Y. TIMES (Feb. 18, 2014), http://www.nytimes.com/2014/02/19/us/public-defenders-turn-to-lawmakers-to-try-to-easecaseloads.html?_r=0.

115. MOTHER JONES, supra note 10 (quoting John Gross of the National Association of
} 
would need to work roughly a year and a half in order to do a year's worth of work. ${ }^{116}$ Managing an unmanageable number of cases means that public defenders must cut corners and triage, putting the most important cases in front of the less serious ones, and moving clients' cases through as expeditiously as possible. According to Stephen Hanlon, chair of an ABA advisory group on indigent defense, "[1]imited resources move to higher-level cases like murder and rape, and thousands of other defendants are simply being thrown under the bus, with the illusion of a lawyer."117

Missouri is one state where caseloads have come under some scrutiny. The American Bar Association commissioned a report titled, The Missouri Project: A Study of the Missouri Public Defender System and Attorney Workload Standards, that was issued in 2014. ${ }^{118}$ The study involved asking public defenders to record the amount of time they spent on various client matters, and comparing this time with "Workload Standards," which were compiled by getting a consensus about the number of hours that were required to perform various client functions adequately. ${ }^{119}$ Among other findings, the report showed that for certain types of felonies, the amount of time spent by Missouri public defenders was less than one fifth of the amount of time suggested by the workload standards. ${ }^{120}$ For probation violations-which can result in significant

\footnotetext{
Criminal Defense Lawyers (NACDL)) ("Many of us don't consider them to be realistic if you expect quality representation."); see also DotTIE CARMichael et AL., Pub. Policy ReSEARCh InST., GUIDELINES FOR INDIGENT DEFENSE CASELOADS iii, v (2015), http://www.americanbar.org/content/dam/aba/events/legal_aid_indigent_defendants/2015/ls_sclaid_ summit_04_texas_study_full_report.authcheckdam.pdf [hereinafter GUIDELINES FOR INDIGENT DEFENSE CASELOADS].

Despite the age of the NAC standards, as well as the myriad of changes in the defense of criminal cases during the past four decades, the standards are still frequently cited as if the recommended numbers are a meaningful measure of maximum defense caseloads that an individual lawyer should be able to represent over the course of a year. In 1973, however, defense lawyers handling criminal cases did not need to worry about collateral consequences of convictions, be familiar with a wide range of forensic evidence, or be Id. called upon to represent defendants in sexually violent offender proceedings.

116. MOTHER JONES, supra note 10.

117. Eckholm, supra note 114; see also GUIDELINES FOR INDIGENT DEFENSE CASELOADS, supra note 115, at vi, ix (Hanlon is also a professor at Saint Louis University School of Law and provides legal representation to the Missouri State Public Defender System).

118. Rubin Brown, Standing Comm. On Legal Aid \& Indigent Defendants, The Missouri Project: A Study of the Missouri Public DeFender System AND AtTorney WORKLOAD $\quad$ STANDARDS 2014$)$, http://www.americanbar.org/content/dam/aba/events/legal_aid_indigent_defendants/2014/1s_sclaid_ 5c_the_missouri_project_report.authcheckdam.pdf.

119. Id. at 5-7.

120. For C/D felonies, public defenders spent 4.4 hours, while the recommended number of
} 
consequences - the study found that defenders in Missouri spent less than an hour-and-a-half all told, when the recommended time was close to ten hours. ${ }^{121}$ In the same year that the report was issued, Stephen Reynolds, chief of the Saint Louis County Public Defender's office noted that some lawyers "were carrying more than [two hundred] felony cases, from drugs to rape and murder.","22 About that load, Reynolds remarked, "I don't think there's any attorney who can handle that, no matter how good you are." 123 With felony cases in the hundreds, public defenders cannot make clear-headed decisions about whether to urge their clients to take a plea; plea deals are a matter of survival.

\section{Crisis Managed: The "Meet 'Em and Plead 'Em" Culture}

U.S. District Court Judge Jed Rakoff has argued that the war on crime, so-called "three strikes" laws, and mandatory minimums have increased the stakes for trials for which public defenders have few resources-ratcheting up the pressure to accept whatever plea is offered. ${ }^{124}$ According to Rakoff,

the direct result [of heavier sentences] was to increase greatly the percentage of criminal cases resolved by guilty pleas .... The indirect results were to move primary responsibility for sentencing from the courts to the prosecutors and, concomitantly, to move the locus of the resolution of most criminal cases from the public forum of the courtroom to the private venue of the prosecutor's office. ${ }^{12}$

The vast majority of cases are disposed by virtue of guilty pleas. ${ }^{126}$ The practice of pleading out a client quickly and with little investigation or deliberation or even communication has been dubbed, "meet 'em and plead 'em." 127 One public defender described the process this way:

\footnotetext{
hours was twenty five. $I d$. at $6,15-17$. For A/B felonies, the workload recommendation was 47.6, as opposed to 8.7 , the actual average hours spent. $I d$.

121. Time spent was 1.4 hours, while the recommendation was 9.8 hours. Id.

122. Eckholm, supra note 114.

123. Id.

124. Jed S. Rakoff, Mass Incarceration: The Silence of the Judges, N.Y. REV. BooKs (May 21, 2015), http://www.nybooks.com/articles/2015/05/21/mass-incarceration-silence-judges/; Jed S. Rakoff, Why Innocent People Plead Guilty, N.Y. REV. BooKs (Nov. 20, 2014), http://www.nybooks.com/articles/2014/11/20/why-innocent-people-plead-guilty/; see also Jed S. Rakoff, Frye and Lafler: Bearers of Mixed Messages, 122 YALE L.J. ONLINE 25, 25-26 (2012) [hereinafter Frye and Lafler] (discussing the impact of the Supreme Court decisions on plea bargaining).

125. Frye and Lafler, supra note 124, at 25-26.

126. See Missouri v. Frye, 132 S. Ct. 1399, 1407 (2012).

127. MOTHER JONES, supra note 10.
} 
A defense attorney arrives in court to represent a new client. She is given a cursory police report and/or complaint. If the attorney is lucky, she may have an opportunity to view ... the client's criminal history. The state makes an offer to the new client, and it sounds decent. ... Perhaps the offer is prison time, but by the defense attorney's understanding of the criminal history, the offer is a lot less time than the client would be facing at trial.

The defense attorney goes back to the holding cell and meets the client for the first time. She introduces herself as the attorney appointed to represent him, lets him know the charges.... If defense counsel is lucky, she will not have to yell over the other noise of similar conversations between countless other attorneys and incarcerated individuals.... [She] informs [the client] that the state has offered a pretty good plea agreement. "You can take the deal now and get this over with," she tells him.

According to Tanya Greene, an ACLU attorney and capital public defender, the primary reason for a large number of accepted plea deals is because of busy defenders prioritizing the most serious offenses and pressuring other clients to accept deals. ${ }^{129}$ "You've got so many cases, limited resources, and there's no relief," Greene says. "You go to work, you get more cases. You have to triage." "130 In November of 2008, public defenders' offices in seven states protested overwhelming workloads, claiming that "the demanding pace of representation ha[d] made the work of these public defenders a 'plea bargain assembly line,' [resulting in] 'less justice and more McJustice.","131

The assembly line analogy stands in stark contrast to the protections envisioned by the authors of the Sixth Amendment trial right, as well as the Fifth and Fourteenth due process rights. ${ }^{132}$ Together, these elements of the Bill of Rights have been interpreted to provide targets of the government — particularly those targets who are most vulnerable — with

128. CeCelia Valentine, Meet 'Em and Plead 'Em: Is This the Best Practice?, ChampION (June 2013), http://www.nacdl.org/Champion.aspx?id=28953.

129. MOTHER JONES, supra note 10.

130. Id.

131. Anchors Away, supra note 36, at 1688-89 (quoting Appleman, supra note 36).

132. "No person shall be... deprived of life, liberty, or property, without due process of law ...." U.S. CONST. amend. V. "In all criminal prosecutions, the accused shall enjoy the right to a speedy and public trial, by an impartial jury of the State and district wherein the crime shall have been committed, which district shall have been previously ascertained by law, and to be informed of the nature and cause of the accusation; to be confronted with the witnesses against him; to have compulsory process for obtaining witnesses in his favor, and to have the Assistance of Counsel for his [defense]." U.S. CONST. amend. VI. "[N]or shall any State deprive any person of life, liberty, or property, without due process of law; nor deny to any person within its jurisdiction the equal protection of the laws." U.S. CONST. amend. XIV, § 1. 
adequate tools to wield a defense against a more powerful state. In keeping with this notion, Stephanos Bibas argues that "[t]he Sixth Amendment presupposes a vigorous, effective adversarial system to test not only defendants' factual guilt but also their culpability and the sentences they deserve." 133 Although public defenders periodically attempt to change the status quo, these efforts have been largely unsuccessful. ${ }^{134}$ There are a small number of notable exceptions. In 2012 and 2013, the state Supreme Courts in Missouri and Florida upheld the right of public defenders in those states to refuse to take non-capital cases, citing a lack of adequate resources. ${ }^{135}$ Florida's highest state court observed that "[a]ttorneys are routinely unable to interview clients, conduct investigations, take depositions, prepare mitigation, or counsel clients about pleas offered at arraignment. Instead, the office engages in 'triage' with the clients who are in custody or who face the most serious charges getting priority to the detriment of the other clients." However, the number of successful refusals is dwarfed by the magnitude of the problem, leading to questions about the legitimacy of the criminal justice system as a whole. After all, liberal political theory dictates that legal processes are only legitimate if they are acceptable to those who are bound by them. ${ }^{137}$

\section{Behind Closed Doors: How the Plea Magnifies Error}

Current deficits in the public defense system increase the chances that defense lawyers will strike bad deals. ${ }^{138}$ Away from the eyes of potential critics, rushed, understaffed, and poorly incentivized-public defenders are ideal candidates for cognitive biases. The indigent defense criminal system is a breeding ground for hastily formed impressions,

133. Stephanos Bibas, Incompetent Plea Bargaining and Extrajudicial Reforms, 126 HARV. L. REV. 150, 169 (2012) [hereinafter Incompetent Plea Bargaining].

134. In Missouri, the state Supreme Court noted the Missouri Public Defender Commission's efforts to correct this:

The commission promulgated 18 CSR $10-4.010$ in response to mounting concern that, due to the growth in the number and complexity of cases requiring public defender services without a corresponding increase in the number of public defenders, some public defenders' caseloads had increased to a level that interfered with their ability to fulfill their constitutional, statutory and ethical obligations to represent their clients effectively and competently.

State ex rel. Mo. Pub. Def. Comm'n v. Waters, 370 S.W.3d 592, 599 (Mo. 2012).

135. Id. at 611-12; Pub. Def. v. State, 115 So. 3d 261, 274 (Fla. 2013).

136. Pub. Def., 115 So. $3 d$ at 274.

137. John Rawls, Political Liberalism 144-50 (1993).

138. Incompetent Plea Bargaining, supra note 133, at 152 (noting "the massive underfunding and overwork that plague indigent defense counsel."). 
rushed decisions, and questionable outcomes. Whereas the courtroom may provide a criminal defendant some additional due process and protection from shoddy or harried lawyering, the plea bargain process does little to illuminate constitutional blunders. ${ }^{139}$ There appears to be no end in sight, in spite of Judge Rakoff's observation that "a criminal justice system operating largely behind closed doors is both inconsistent with the traditions of a free society and an invitation for abuse."140 Ironically, the same pressures that lead to lawyering mistakes (oversights, missed deadlines, lack of investigation) also help to perpetuate plea bargains.

Evidence suggests that some prosecutors exploit the system of sloppy justice by engaging in upcharging and overcharging, and using various techniques such as anchoring to increase the palatability of an offer. $^{141}$ Threats are often part of a prosecutor's arsenal as well. One judge remarked:

Underlying many plea negotiations is the understanding - or threatthat if the defendant goes to trial and is convicted he will be dealt with more harshly than would be the case if he had pleaded guilty. An innocent defendant might be persuaded that the harsher sentence he must face if he is unable to prove his innocence at trial means that it is to his best interest to plead guilty despite his innocence.

A number of observers have commented on the propensity for prosecutors to make errors in decisions about whom and what to charge. Prosecutors, like other human beings, are subject to cognitive errors that can influence their perception of targets of an investigation. These errors make a defendant seem more culpable, and can even lead a prosecutor to target the wrong person. ${ }^{143}$ A plea bargain effectively strengthens and confirms any biased judgments that may exist in the preliminary stages of pretrial preparation. Because there is no trial, the standard of proof applied by the architects of the deal is unknown, and the results are

139. See Stephen B. Bright, Counsel for the Poor: The Death Sentence Not for the Worst Crime but for the Worst Lawyer, 103 YALE L.J. 1835, 1842, 1852 (1994) (noting instances in which even in the context of a trial, lawyers have performed abysmally).

140. Frye and Lafler, supra note 124, at 26; see also Eve Brensike Primus, Structural Reform in Criminal Defense: Relocating Ineffective Assistance of Counsel Claims, 92 CORNELL L. REV. 679, 682-83 (2007) (discussing reasons for allowing appellate attorneys to raise ineffective assistance of counsel arguments during appeals).

141. See Shadow of Trial, supra note 34, and accompanying text.

142. Ralph Adam Fine, Plea Bargaining: An Unnecessary Evil, 70 MARQ. L. REV. 615, 622 (1987) (quoting U.S. NAT'L AdVISORY COMM'N OF CRIMINAL JUSTICE, COURTS 43 (1973)).

143. See infra notes 219-25 and accompanying text (identifying biases influencing defense attorneys and prosecutors alike); see Kertscher, supra note 40 and accompanying text. 
largely irreversible. As Justice Scalia noted, in comparing pleas to trial, a jury trial is "the 24-karat test of fairness," and "the best thing [that] our legal system" has to offer. ${ }^{144}$ By and large, the process that leads to a defendant's penalty falls far short of this.

\section{E. Courts Protect Plea Bargain System}

In spite of widespread acknowledgment of an inadequate system of indigent representation and acceptance that plea deals are the rule, rather than the exception, "the Supreme Court has usually treated plea bargaining as an afterthought, doing little to regulate it."145 In fact, when the Court has considered the practice, it has been supportive of the current state of affairs. Nancy Jean King argues that the Court's interpretation of the Constitution expanded to afford criminal defendants more technical protection and that the Court then turned a blind eye to inadequacies and shortcomings that denied defendants the very protection the Court purported to find. ${ }^{146}$ The Court has called plea bargains "important components of this country's criminal justice system," 147 and has characterized such deals as "essential" and "highly desirable part[s]" of the criminal process that lead to "prompt and largely final disposition of most criminal cases." 148 Courts do not control the amount of funding available for indigent defense, and there is little that they can do to influence legislatures. As a result, there is little courts can do to address flaws in the system, short of overturning pleas and convictions. Meanwhile, as Chief Justice Burger noted, "If every criminal charge were subjected to a full-scale trial, the States and the Federal Government would need to multiply by many times the number of judges and court facilities." 149

The Justices on the Supreme Court are all too aware of the pressures facing lower courts. For decades, observers of courts and judges alike have been writing about the tendency of trial courts to have overloaded

\footnotetext{
144. Transcript of Oral Argument at 13, Lafler v. Cooper, 132 S. Ct. 1376 (2012) (No. 10-209), 2011 WL 5131273

145. Incompetent Plea Bargaining, supra note 133, at 150; see also MARKUS DIRK DUBBER, THE POLICE POWER 179 (2005) ("The plea bargaining process is governed by very few, if any, principles, with the blessing of the Supreme Court which has turned a blind constitutional eye.").

146. Nancy Jean King, Priceless Process: Nonnegotiable Features of Criminal Litigation, 47 UCLA L. REV. 113, 122-23 (1999) (identifying the "due process revolution" as a mechanism that led to the Court's "endorsement in the 1970s of plea bargaining itself.").

147. Blackledge v. Allison, 431 U.S. 63, 71 (1977).

148. Santobello v. New York, 404 U.S. 257, 261 (1971).

149. Id. at 260 .
} 
dockets. ${ }^{150}$ Trial court judges who preside over a large number of cases are not well positioned to stem the tide of hastily negotiated plea deals. In fact, the motivations created by limited resources in the criminal justice system are similar to those of prosecutors and the criminal defense bar. Bibas notes that "[ $\mathrm{t}$ ] rial judges have strong incentives to clear their own dockets by encouraging defendants to accept deals and making those deals bulletproof." 151 Because these deals are offered, discussed, and negotiated behind closed doors, judges often have little information upon which to determine whether the decision to accept is truly a defendant-informed one.

\section{THE PROBLEM OF INNOCENCE}

One of the most compelling arguments for a change in the system is the fact that innocent defendants accept plea deals. DNA exonerations are clear evidence that criminal defendants $d o$ sometimes agree to serve time when they are innocent. ${ }^{152}$ It may be perfectly rational for an innocent defendant to accept a plea. In situations in which the prosecutor appears convinced of the defendant's guilt and the defense lawyer is doing little to fight for him, he may conclude that his best option is to cut his losses and take whatever deal the prosecutor is offering. In such an instance, the defendant's compliance is administratively convenient, but it does not serve the interest of justice. ${ }^{153}$ A criminal trial puts the burden

150. More than thirty-five years ago, Judge William Schwarzer, a federal judge for the Northern District of California, wrote about the feasibility of trial judge oversight of defense counsel. William W. Schwarzer, Dealing with Incompetent Counsel-the Trial Judge's Role, 93 HARV. L. REV. 633, 633, 665 (1980). He asked:

Is it realistic to expect a judge, heavily burdened with a growing backlog of criminal cases, to indulge in the apparent luxury of pretrial conferences, sua sponte inquiries into the adequacy of counsel's preparation, and consideration of objections, defenses and posttrial motions? Even if these proposals are feasible in courts having light dockets, how could they be applied in large metropolitan courts where criminal cases are dispatched on an assembly line basis?

Id. at 665. See also Janet Stidman Eveleth, Dispute Resolution Comes of Age, 36 MD. B.J., July/August 2003, at 1, 4 (observing that in Maryland, "[w]ell over two million cases are filed in the state's trial courts every year, burdening courts with overloaded dockets."); McCoy v. Wal-Mart Stores, Inc., 59 S.W.3d 793, 801 (Tex. 2001) (noting that Texas trial courts have authority to limit voir dire examinations in order to manage over-burdened dockets); Elizabeth T. Lear, Congress, the Federal Courts, and Forum Non Conveniens: Friction on the Frontier of the Inherent Power, 91 IOWA L. REV. 1147, 1154, 1157 (2006) (remarking on "congestion" in federal courts).

151. Incompetent Plea Bargaining, supra note 133, at 165.

152. Brandon L. Garrett, Judging Innocence, 108 CoLUM. L. REV. 55, 73-75 (2008) (noting that nine people out of a two-hundred person sample pleaded guilty to either rape and/or rape and were later exonerated through DNA testing); see Richard Birke, Reconciling Loss Aversion and Guilty Pleas, 1999 UTAH L. REV. 205, 216 (1999) [hereinafter Reconciling Loss Aversion].

153. The prosecutor is charged with seeking justice, the people's interest is a fair system that 
of proof on the state, and because trial preparation involves information gathering, going to trial provides the opportunity for the truth to become clear, even if it was obscured at an earlier stage.

Research into the phenomenon of false confessions provides some clues as to what pressures lead to false admissions of guilt. ${ }^{154}$ Saul Kassin and other social psychologists have studied the false confession context extensively, and through empirical studies, these researchers have demonstrated that it is surprisingly easy to get someone to confess to a "crime" he or she did not commit. ${ }^{155}$ Through careful experimentation and analysis, these researchers have been able to identify situational pressures that lead to false confessions. The pressures include a desire to escape from a bad situation, the urging of an influential person, and the feeling of a loss of control. ${ }^{156}$ Often these factors are present for the indigent defendant who is facing serious criminal charges.

\section{A. Pressures and the Compliant Defendant}

In the plea deal context, criminal defendants face a host of pressures that together, can lead them to accept deals offered by a prosecutor. ${ }^{157}$ In fact, when investigative (interview) techniques have led a defendant to confess, that defendant is more likely to accept a plea and offer a false admission. Researchers Drizin and Leo compiled 125 false confession cases and found that of those 18- to 24-year-old defendants who were prosecuted, 27\% had pled guilty. ${ }^{158}$ Empirical evidence demonstrates

accurately sorts the innocent from the defendant, and the defense lawyer's interest is in zealous and successful representation.

154. Saul M. Kassin \& Rebecca J. Norwick, Why People Waive Their Miranda Rights: The Power of Innocence, 28 LAW \& HuM. BeHAV. 211, 211-21 (2004) [hereinafter Why People Waive Their Miranda Rights] (finding in a mock crime experiment that innocent suspects are more likely to waive their Miranda rights to silence and to counsel even when in the presence of an officer who appears guilt-presumptive, hostile, and closed-minded).

155. Individual differences notwithstanding, there are two structural aspects of a typical police interrogation that are striking to this social psychologist. Saul M. Kassin, False Confessions: Causes, Consequences, and Implications for Reform, 1 POL'Y INSIGHTS FROM BEHAV. \& BRAIN SCI. 112,115 (2014). The first concerns the fact that "interrogation is by definition a guilt-presumptive social interaction led by an authority figure who has formed a strong belief about the suspect," sometimes through a pre-interrogation interview, and "who single-mindedly measures success" by whether he or she is able to extract a confession. Id. "The guilt-presumption that marks the start of interrogation thus provides fertile ground for the operation of cognitive and behavioral confirmation biases." Id.

156. See generally Jennifer T. Perillo \& Saul M. Kassin, Inside Interrogation: The Lie, the Bluff, and False Confessions, 35 LAW \& HuM. BEHAV. 327 (2011).

157. See Why People Waive Their Miranda Rights, supra note 154, at 218.

158. Steven A. Drizin \& Richard A. Leo, The Problem of False Confessions in the Post-DNA 
that incriminating evidence-even when the evidence is suspectinfluences perceptions of guilt. For example, one mock-juror study by Kukucka and Kassin revealed that knowledge of a recanted confession can taint evaluations of handwriting evidence. ${ }^{159}$ When told that the defendant had confessed-even though he later retracted his confession, claiming it was coerced-participants perceived the handwriting samples as more similar and were more likely to conclude, erroneously, that they were authored by the same individual. ${ }^{160}$ Research on the confirmation bias and the effects of false confessions on subsequent beliefs of mock jurors and investigators suggest the possibility that confessions can corrupt other evidence. The same assumptions and biases that influence jurors can work on a defendant's own lawyer. So a public defender who has a confessing client may be more likely to believe the client is guilty and will be disinclined to spend time and resources to investigate. The Innocence Project has reported on more than 300 such post-conviction DNA exonerations, all involving rape or murder. ${ }^{161}$

Because of the constraints facing both prosecutors and defense lawyers, pretrial information gathering and negotiations do not adequately sort guilty and innocent defendants. ${ }^{162}$ One theory explaining the sorting problem involves the idea of "pooling." 163 Bob Scott and Bill Stuntz coined the phrase pooling in the context of prosecutorial decisionmaking. ${ }^{164}$ Prosecutors typically process a large number of cases. Like defense attorneys, they lack adequate resources to investigate all (or even most) claims of innocence. If prosecutors were to take defendants at their word, they would be forced to drop most charges. Faced with two unworkable options-fully investigating or dropping chargesprosecutors do the predictable, and treat guilty and innocent defendants

World, 82 N.C. L. Rev. 891, 945 (2004) [hereinafter The Problem of False Confessions].

159. Jeff Kukucka \& Saul M. Kassin, Do Confessions Taint Perceptions of Handwriting Evidence?: An Empirical Test of the Forensic Confirmation Bias, 38 LaW \& HuM. BeHaV. 256, 265-67 (2014).

160. Id.

161. DNA Exonerations in the United States, INNOCENCE PROJECT, http://www.innocenceproject.org/dna-exonerations-in-the-united-states/ (last visited Oct. 10, 2016). In nearly $30 \%$ of these cases, false confessions were a contributing factor-and this sample represents only a fraction of all wrongful convictions. Id. See also GARRETT, supra note 19.

162. See Margaret A. Neale \& Max H. Bazerman, Cognition and Rationality in NegOtiation 170-72 (1991); Rebecca Hollander-Blumoff, Social Psychology, Information Processing, and Plea Bargaining, 91 MARQ. L. REV. 163, 182 (2007) [hereinafter Social Psychology Information Processing].

163. Plea Bargaining as Contract, supra note 2, at 1911.

164. See id. at 1947. 
alike. ${ }^{165}$ The similar treatment for all defendants means that there is "no downward innocence adjustment." 166 Defense attorneys also tend to treat similarly situated clients similarly. ${ }^{167}$ Good criminal defense attorneys make initial assessments about how to prioritize cases-so some initial sorting is done-but once they have decided on an appropriate course of action, severe time constraints as well as confirmation (and related) biases suggest that they are unlikely to do additional investigation. ${ }^{168}$

\section{B. Lawyer as Counselor \& Arm-Twister}

Once a defense lawyer has decided that a plea is acceptable, she communicates the deal to her client. At that point, ostensibly, the lawyer's job is to counsel her client. The term "counselor" is rooted in the idea that the lawyer advises the client, while the client makes the decisions. The ABA defines the role this way: "As advisor, a lawyer provides a client with an informed understanding of the client's legal rights and obligations and explains their practical implications." 169 Courts have reinforced this notion in their opinions, defining the obligation of the criminal defense lawyer as limited to providing the client with reasonable options from which the client may choose. ${ }^{170}$ The notion that the client should be in charge of important decisions has been central to a number of Supreme Court decisions. The Court has acknowledged that criminal defendants have more than an interest- they have the right to control the disposition of their case. ${ }^{171}$

\footnotetext{
165. See id. at $1947,1952-53$.

166. Id. at 1947.
}

167. See Robert E. Scott \& William J. Stuntz, A Reply: Imperfect Bargains, Imperfect Trials, and Innocent Defendants, 101 YALE L.J. 2011, 2012 (1992)(speaking generally about the fact that "the pooling problem we have identified goes to the core function of the process: its ability to separate the innocent from the guilty.")

168. Id. at 176-77 (arguing that "defense lawyers, especially those whose clients are incarcerated or who have an indictment hanging over them, may be eager to get charges resolved.").

169. Model Rules of Prof'L Conduct, Preamble \& Scope, cl. 2 (AM. BAR Ass'N 2016).

170. See Robert F. Cochran, Jr., Crime, Confession, and the Counselor-at-Law: Lessons from Dostoyevsky, 35 Hous. L. REV. 327, 329-30 (1998) (describing State v. Holland, 876 P.2d 357, 363 (Utah 1994) (Stewart, J., concurring)) ("Justices Stewart and Durham of the Utah Supreme Court ... stated, '[i]t is not the role of defense counsel to persuade a defendant to plead guilty because counsel concludes that the defendant committed a crime.' Such a role would 'nullify our adversarial system and ... deny the defendant the effective assistance of counsel.' The justices suggested that defense counsel should merely explain the options to the client and allow the client to choose whether to plead guilty.").

171. See, e.g., Brookhart v. Janis, 384 U.S. 1, 7-8 (1966) (holding that counsel cannot waive the decision whether to plead guilty or hold the government to its burden of proof at trial over the defendant's objection). 
In spite of the mandates of the American Bar Association and the Supreme Court, lawyers who represent indigent criminal defendants sometimes exert considerable pressure on the client to accept a plea. The pressure that comes from a defendant's own lawyer may be the most influential. ${ }^{172}$ The practice of using psychological pressure to get clients to plead is well represented in legal scholarship. Scholar-practitioners have pondered the ethical implications of various tactics to convince clients to go to trial. ${ }^{173}$ Some of these tactics include: enlisting "capital experts" who will recount stories of trials that culminated in death sentences, getting family members to implore the client to take a plea to spare the family, and using religion as a basis for arguing that the defendant could be making a difference for fellow prisoners. ${ }^{174}$ Abbe Smith argues in favor of "using a considerable amount of persuasion to convince the client that a plea which the client instinctively disfavors is, in fact, in his or her best interest." 175 She goes on to note that the "persuasion is most often needed to convince the client that $\mathrm{s} /$ he should plead guilty in a case in which a not guilty plea would be destructive."176

There is wide-spread acceptance of strong-arm tactics in influencing defendants to accept plea deals. ${ }^{177}$ However, some observers have called these tactics into question. ${ }^{178}$ One concern is that a harried defense attorney often does not have the time to discern whether her client could be cleared of the charges with additional investigation and evidence-

172. Some efforts have been made to shift the focus to a model of client choice. A well-known example is DAVID A. Binder \& SusAn C. PRICE, Legal INTERVIEWING AND Counseling: A Client-Centered APPROACH (1977) (joined by Paul Bergman in the text's second edition) [hereinafter BINDER \& PRICE]. A central theme is client decision-making. For a discussion of this approach, see Alexander Scherr, Lawyers and Decisions: A Model of Practical Judgment, 47 VILL. L. REV. 161, 190 (2002).

173. This author has not found examples of attorneys discussing psychological tactics and pressure to convince defendants to give up the deal to go to trial.

174. Abbe Smith, The Lawyer's "Conscience" and the Limits of Persuasion, 36 HofSTRA L. Rev. 479, 485-87 (2007) (citing Kevin M. Doyle, Heart of the Deal: Ten Suggestions for Plea Bargaining, 23 CHAMPION, Nov. 1999, at 68, 70).

175. Id. at 481 (citing Anthony G. Amsterdam, Trial Manual 5 for the Defense of CRIMINAL CASES $\S 201$, at 339 (5th ed. 1988)).

176. Id. See also The Defense Attorney's Role in Plea Bargaining, supra note 2, at 1309 (noting that under the American guilty plea system, "the line between advice and coercion seems virtually nonexistent" because "accurate advice is almost always coercive").

177. See infra notes $179-83$ and accompanying text.

178. Peter W. Tague, Guilty Pleas and Barristers' Incentives: Lessons from England, 20 GEO. J. Legal Ethics 287, 287 (2007) ("Criminal defense lawyers in the United States sometimes pressure clients to plead guilty. The purpose could be defensible, even laudable: to eliminate the risk that the defendant, guilty or provably so, would be sanctioned much more harshly if convicted at trial. The purpose could also be pernicious: to advance the lawyer's interests when it would be 'better' for the defendant to contest guilt.") (citations omitted). 
gathering. The defendant who holds out may have information that could clear him, or he may be aware of weaknesses in the prosecutor's case-information to which the attorney does not, at the initial stages, have access. Because the attorney controls communication with the prosecutor, has access to the file, and possesses greater familiarity with the process her influence is profound. The average indigent defendant sitting in jail awaiting trial is not even able to decide when and how often to meet with his lawyer - he must wait for her to initiate contact. ${ }^{179}$

A criminal defendant who has little hope of receiving significant attention from his lawyer beyond communication urging him to accept a deal and who has nobody else in his corner with means to fight for him may conclude that a deal is his only option. He may reach this conclusion even if he knows he is innocent of the charges. The current "meet "em and plead "em culture" dis-incentivizes public defenders to investigate claims of innocence. ${ }^{180}$ It simultaneously perpetuates a system in which innocent defendants are incentivized to admit false guilt. As prominent Judge Frank Easterbrook has noted, "[p]ersons at risk of unjust conviction may prefer a certain (but low) punishment in a plea bargain to the risk of conviction and high punishment after trial." 181 One extensive study of plea bargaining found that uncounseled defendants who are not guilty may choose to obtain concessions by pleading guilty. ${ }^{182}$ Meanwhile, examples of innocent people being punished abound. The "Rampart" scandal in Los Angeles, California and another in Tulia, Texas, are two examples suggesting that, "at least under certain conditions, wrongly accused innocent defendants routinely plead guilty.",183

179. See Perisha Wallace, No Equal Justice for the Poor: Mississippi's Failed Attempt to Honor Right to Counsel Mandates, 9 S. J. POL'Y \& JUST. L.J. 81, 87 (2015) (providing the example of a defendant who could not afford bail and remained in jail for over eleven months without receiving a single visit from a lawyer); Eve Brensike Primus, The Illusory Right to Counsel, 37 OHIO N.U. L. REV. 597, 601 (2011) ("In many jurisdictions, attorneys routinely meet their clients for the first time on the trial court date.").

180. Jed S. Rakoff, Why Innocent People Plead Guilty, N.Y. Rev. BooKs, (Nov. 20, 2014), http://www.nybooks.com/articles/2014/11/20/why-innocent-people-plead-guilty/. Drizin and Leo assembled for analysis 125 false confession cases and found that of those 18- to 24-year-old defendants who were prosecuted, $27 \%$ had pled guilty. The Problem of False Confessions, supra note 158 , at 945 .

181. Frank H. Easterbrook, Plea Bargaining as Compromise, 101 YALE L.J. 1969, 1969 (1992) (agreeing with Scott and Stuntz, who "are concerned that the innocent cannot adequately identify themselves in the bargaining process, so they may not receive the discount their status implies.").

182. See Donald J. Newman, Conviction: The Determination of Guilt or InNocence Without TRIAL 200-05, 225-26 (1966).

183. Russell D. Covey, Plea-Bargaining Law After Lafler and Frye, 51 DuQ. L. REV. 595, 616 (2013). 
In both Rampart and Tulia, large numbers of prisoners were exonerated after it was discovered that law enforcement officials had engaged in large-scale misconduct causing the wrongful conviction of scores of innocent persons. Police misconduct ranged from the planting of false evidence to police perjury. In those two scandals, of sixty four actually innocent exonerees, $81 \%$, or 52 out of 64 , pled guilty after having been falsely accused of engaging in criminal conduct by untruthful police officers. ${ }^{184}$

Even in the case of criminal defendants who are guilty of some chargeable offense, distracted lawyering, pressure to plead and little oversight lead to concerns about whether the plea deals capture the right amount of punishment.

\section{THe DeCision: Whose CHOICE?}

Indigent criminal defendants accept plea deals in the vast majority of all cases. They surrender their right to a trial in exchange for a promise of some measure of leniency. ${ }^{185}$ In so doing, they forfeit the right to make the state prove its case, and they agree to probation or prison time, and all of the consequences that go along with the resulting conviction. ${ }^{186}$ As a result, "plea bargaining substitutes the values of administrative efficiency in the criminal process for the values of trial."187 The lawyer - most often a public defender-moves on to the next client. Meanwhile, the defendant is left to deal with the fallout; it is the defendant, and not his lawyer, who lives with the consequences of the decision to accept the deal.

184. Id. (citations omitted).

185. Because of the potential for strategic charging decisions, it is difficult to say in all cases whether the defendant actually receives a good bargain. Were the case to go to trial, the prosecutor would have to charge only what she could prove, and this is not truly tested pretrial.

186. In addition to giving up the right to a trial and trial protections offered through the Fifth and Sixth Amendments to the U.S. Constitution, the possibility of acquittal, and often the assurance of punishment ranging from time in prison, to probation, to fines, a defendant will experience "collateral consequences." The American Bar Association defines collateral consequences as "opportunities and benefits that are no longer fully available to a person, or legal restrictions a person may operate under, because of their criminal conviction." User Guide Frequently Asked Questions, ABA NAT'L InVEnTORY COllateral CONSEQUENCES CONVICTION, http://www.abacollateralconsequences.org/user_guide/\#q01 (last visited Oct. 9, 2016). Well-known examples are the loss of the right to vote, and the placement of a convict's name on the sex offender registry. See id.

187. The Unconstitutionality of Plea Bargaining, 83 HARV. L. REV. 1387, 1405 (1970). 


\section{A. Lawyer Bias and the Rush to the Deal}

No doubt, the majority of lawyers who represent indigent defendants counsel them to accept a deal only when to do so seems like a reasonably good option. But what seems like a good option to a defense lawyer may be influenced by a number of factors; of the various factors that explicitly or implicitly influence defense attorneys, not all are specific to that client, and not all should be considerations in the case of a given defendant. Facing too many clients and too little time, defense attorneys have to weigh the needs of clients against each other, make guesses about what they might find if they had more resources for investigation, and strike a reasonable balance between personal life and professional goals. Even a diligent public defender can be influenced by motivational biases that make a wheel-and-deal system of criminal justice seem more palatable. Most biases influencing public defenders point in a single direction: toward the speedy disposition of a case in a plea deal.

Even in cases in which the defense attorney is diligent and wellintentioned, taking control of the decision to plead guilty can deprive a criminal defendant of a chance he would not otherwise have had. In fact, some of the value of going to trial is the preparation; even a mediocre defense attorney will do some investigation and planning in preparation for trial, and this may turn up mitigating or exculpatory evidence. There are at least three reasons why proceeding to trial can advantage a defendant. The first is that trial preparation can expose weaknesses in the prosecution's case. The second is that a trial is more likely to serve as a check on bad defense lawyers-forcing them to do the work they would otherwise avoid, and in the event that they do not, exposing their inadequacies. The third is that the credible threat of having to prove the case may impact a prosecutor's view of the case. According to Judge Rakoff, " $[\mathrm{M}]$ ost of the unfairness that occurs during the plea-bargaining process is, in my experience, ... the result of overconfidence on the part of prosecutors, whose evidence and sources, having never been put to the test of a trial, appear much stronger . . . than is objectively warranted." 188

\footnotetext{
188. Frye and Lafler, supra note 124, at 26 ("For example, a prosecutor, intent on ensnaring as many defendants as possible, is often more prone to credit a cooperator's testimony than a jury that has heard the cooperator cross-examined by effective defense counsel would be.").
} 


\section{B. Court Preference for Lawyer Choices}

Although the framers of the Constitution envisioned a criminal justice system with checks on lawyers, ${ }^{189}$ courts have migrated away from this initial skepticism, holding that the attorney retains ultimate control over many decisions, "even when the defendant expresse[s] a contrary wish to his lawyer." 190 One example is the case of Haynes $v$. Cain ${ }^{191}$ in which the defendant was charged with first-degree murder. ${ }^{192}$ The government's theory-and burden of proof under the relevant criminal code — was that the defendant had intentionally killed the victim during the course of a rape or robbery. ${ }^{193}$ Although the charge was a death penalty-eligible offense, and the defendant strenuously objected, defense counsel conceded that his client had committed the rape-robbery, arguing that the defendant was guilty of second-degree murder, and should be spared the death penalty. ${ }^{194}$ The Fifth Circuit, sitting en banc, held that defense counsel's refusal to comply with his client's wishes did not constitute ineffective assistance of counsel. ${ }^{195}$ In United States $v$. Burke, the Eleventh Circuit, the court said,

Defense counsel in a criminal trial is more than an adviser to a client with the client's having the final say at each point.... [H] is chief reason for being present is to exercise his professional judgment to decide tactics.

189. Erica J. Hashimoto, Resurrecting Autonomy: The Criminal Defendant's Right to Control the Case, 90 B.U. L. REV. 1147, 1166 (2010) [hereinafter Resurrecting Autonomy] (citations omitted) ("The suspicion of lawyers arose at least in part from the fact that after the Revolution, there was a dearth of high quality lawyers in practice since many had returned to England or had left practice to become active in politics or to serve on the bench. Second, lawyers were associated with the upper class, and those who were poor often could not afford lawyers."). See also Faretta v. California, 422 U.S. 806, 826 (1975) ("The colonists brought with them an appreciation of the virtues of self-reliance and a traditional distrust of lawyers.").

190. United States v. Burke, 257 F.3d 1321, 1324 (11th Cir. 2001). The 11th Circuit thought that it was sufficient to note that "[w]hen the defendant is given the last word about how his case will be tried, the defendant becomes his own trial lawyer," and used this rationale as a clear basis for limiting defendant involvement in retrial and trial decisions. Id. at 1323-24. The court held that the decision to request a mistrial was a tactical decision that fell within "the province of defense counsel" and was not a fundamental decision that belonged to the defendant. Id. at 1324 .

191. 298 F.3d 375 (5th Cir. 2002).

192. Id. at 377.

193. Id.

194. Id. at $377-78$.

195. Id. at 382-83 (holding that Haynes failed to overcome the prejudice prong of the Strickland test due to what the court described as "overwhelming evidence" against Haynes). 
... [T]he adversarial system becomes less effective as the opinions of lay persons are substituted for the judgment of legally trained counsel. ${ }^{196}$

The Supreme Court has similarly expressed a preference for counselled criminal defense. With respect to cases in which the defendant wishes to represent himself, the Court has said, "[a]lthough we found in Faretta that the right to defend oneself at trial is 'fundamental' in nature, it is clear that it is representation by counsel that is the standard, not the exception." 197 The Court has compared a defendant's courtroom efforts disfavorably to that of a lawyer's, ${ }^{198}$ arguing that "to decide what issues are to be pressed... seriously undermines the ability of counsel to present the client's case in accord with counsel's professional evaluation." 199

Supreme Court jurisprudence has, in multiple instances, viewed defendants' choices regarding trial strategy to be misguided and uninformed. The highest Court has gone so far as to concur with comments from the ABA suggesting that criminal defendants might not even have the capacity to understand trial rights. ${ }^{200}$ The notion that a defendant cannot understand protections captured by the Fifth and Sixth Amendments is important, because these are the areas the Court has identified as fundamental rights, belonging to the defendant. These rights include whether to waive the right to a jury trial, ${ }^{201}$ whether to take the stand, ${ }^{202}$ whether to pursue an appeal ${ }^{203}$ as well as the right to accept

196. Burke, 257 F.3d at 1323. The court went on to say "[w]hen the defendant is given the last word about how his case will be tried, the defendant becomes his own trial lawyer." Id.

197. Martinez v. Court of Appeal of Cal., Fourth Appellate Dist., 528 U.S. 152, 161 (2000) (citations omitted). See Patterson v. Illinois, 487 U.S. 285, 307 (1988) (noting the "strong presumption against waiver" of right to counsel).

198. "Our experience has taught us that 'a pro se defense is usually a bad defense, particularly when compared to a defense provided by an experienced criminal defense attorney.'" Martinez, 528 U.S. at 161 (quoting John F. Decker, The Sixth Amendment Right to Shoot Oneself in the Foot: An Assessment of the Guarantee of Self-Representation Twenty Years After Faretta, 6 SETON HALL CONST. L.J. 483, 485 (1996)).

199. Jones v. Barnes, 463 U.S. 745, 751 (1983).

200. Gonzalez v. United States, 553 U.S. 242, 249 (2008) (citing ABA CRIMINAL JuSTICE STANDARDS, Defense Function $\S$ 4-5.2, Commentary, at 202 (3d ed. 1993), which states that "[m] any of the rights of an accused, including constitutional rights, are such that only trained experts can comprehend their full significance, and an explanation to any but the most sophisticated client would be futile.").

201. Adams v. United States ex rel. McCann, 317 U.S. 269, 275 (1942).

202. Rock v. Arkansas, 483 U.S. 44, 51-53 (1987).

203. Fay v. Noia, 372 U.S. 391, 438-39 (1963), abrograted by Coleman v. Thompson, 501 U.S. 722 (1991). 
or reject a plea ${ }^{204}$ and the right to represent oneself. ${ }^{205}$ Although control over these last two areas would significantly expand overall control for the defendant, evidence from case law and the trenches paint a complicated picture. ${ }^{206}$

In addition to questioning a defendant's ability to understand and make good decisions, the Court has used an efficiency line of reasoning to supplant client choice with attorney decision-making. The Court has held, somewhat quixotically, that a defendant's legitimate autonomy interest can be balanced against "the overriding state interest in the fair and efficient administration of justice." 207 Courts have also held that with respect to many strategic decisions, attorneys may make decisions, even without so much as consulting with their clients. The rationale has often been administrative facility. In Gonzalez, for example, the Court said, "[g]iving the attorney control of trial management matters is a practical necessity. "The adversary process could not function effectively if every tactical decision required client approval." ${ }^{208}$ Even the waiver of certain rights have been ceded to the attorney. ${ }^{209}$ The Supreme Court's participation in the diminishment of defendant control has not gone unnoticed, nor uncriticized. ${ }^{210}$ Clearly, where a client is nonresponsive, and counsel attempts to communicate a strategy choice, there may be legitimate reasons to allow counsel to move forward with her preferred course of action. ${ }^{211}$ However, where a client has a preference over how his defense should be conducted, his choice should be respected. It is disconcerting that the Court cited the ABA with

204. Boykin v. Alabama, 395 U.S. 238, 242 (1969).

205. Faretta v. California, 422 U.S. 806, 819-20 (1975). See also United States v. Teague, 953 F.2d 1525, 1531 (11th Cir. 1992) (recognizing that "[c]riminal defendants possess essentially two categories of constitutional rights: those which are waivable by defense counsel on the defendant's behalf, and those which are considered 'fundamental' and personal to [the] defendant, waivable only by the defendant.").

206. See supra notes 138-51, 190-98 and accompanying text.

207. Martinez v. Court of Appeal of Cal., Fourth Appellate Dist., 528 U.S. 152, 163 (2000). Jones v. Barnes, 463 U.S. 745, 751 (1983) (noting that tactical (non-fundamental) rights can be decided by counsel).

208. Gonzalez v. United States, 553 U.S. 242, 249 (2008) (quoting Taylor v. Illinois, 484 U.S. 400, 418 (1988)).

209. "To hold that every instance of waiver requires the personal consent of the client himself or herself would be impractical." Id. at 250. In Gonzalez, the defendant was never consulted regarding his desire to have a magistrate judge - not a district judge - to preside over voir dire. Id. at 244. Indeed, the criminal defendant needed an interpreter, who was not present when the waiver was made. $I d$.

210. Fear of Adversariness, supra note 17, at 2555-56 (“[T]he Court suspects that, if they were truly [sic] captains of their own ships, defendants would insist upon more adversary procedures than do their lawyers.").

211. Florida v. Nixon, 543 U.S. 175, 187-92 (2004). 
approval when it said, "[e]very experienced advocate can recall the disconcerting experience of trying to conduct the examination of a witness or follow opposing arguments or the judge's charge while the client 'plucks at the attorney's sleeve' offering gratuitous suggestions." 212

The control that courts have ceded to attorneys in criminal trials seems at odds with other areas of law, and is hard to justify using the typical rights-based approach so often used when discussing criminal procedure. This disjunction has not gone unnoticed by legal scholars. Pamela Metzger has argued that "one of the Court's primary means of regulating trial adversariness (sic) has been to reduce defendant control over the invocation of Sixth Amendment adversarial procedures . . .."213 Vivian Berger has noted the trepidation that the Court has "placed a great deal of power in the hands of attorneys [and] ... bound the [defendant] after the fact to virtually all of counsel's decisions and derelictions ...."214 Metzger has also pointed out that "[a] criminal defense attorney's obligations as an agent do not 'mirror the obligations of a general agent representing his principal on civil matters.' ... [C]onstitutional criminal procedure limits the scope of the authority of the criminal defense attorney-agent and the criminal defendantprincipal.",215

\section{SHIFTING POWER: Giving CHOICE BACK TO THE DEFENDANT}

Multiple variables, including too little court oversight, a paucity of resources, the structure of negotiations, and power imbalances, increase the number of judgment errors for criminal defense attorneys, resulting in too many ill-advised plea bargains. By giving choice back to the defendant, the role of factors that currently encourage too little information exchange, suboptimal decisions, and hasty plea deals would be minimized. Giving indigent defendants more control over decisions would address a number of problems that have plagued the criminal justice system, including the protection of individual trial and pretrial

212. Gonzalez, 553 U.S. at 249-50 (citing ABA Criminal Justice Standards, Defense Function $\S 4-5.2$, Commentary, at 202 (3d ed. 1993)).

213. Fear of Adversariness, supra note 17, at 2555.

214. Vivian O. Berger, The Supreme Court and Defense Counsel: Old Roads, New Paths-A Dead End?, 86 Colum. L. ReV. 9, 26 (1986).

215. Fear of Adversariness, supra note 17, at 2567-68 (citations omitted). 
rights, the proliferation of "McJustice" and "meet-em-and-plead-em" practices, and a lack of faith in criminal justice outcomes. ${ }^{216}$

\section{A. Leveraging the Power of the Defendant}

The current system affords the prosecutor an enormous amount of power. ${ }^{217}$ This power comes from the prosecutor's authority to decide which charges to bring against a defendant and what deal-if any-to offer the defendant, to say nothing of her choice of trial strategy (should the case proceed to trial) and her ability to make sentencing recommendations. ${ }^{218}$ Although the prosecutor is charged with "seeking justice" and not simply securing a conviction, once a prosecutor has zeroed in on a person of interest, her desire to secure a conviction for the people can interfere with the justice seeking function. The competing obligations of the role of the prosecutor are complicated by the fact that cognitive biases exert influence on her decision-making, tending to make suspects appear to be guilty of the offense. ${ }^{219}$ Moreover, although a prosecutor tends to have more resources than a public defender, the prosecutor operates under similar pressures, stemming from heavy caseloads. $^{220}$

The large number of cases that come through the criminal justice system mean that prosecutors rely heavily on plea bargains to function. ${ }^{221}$ Like public defenders, "[p]rosecutors have strong self-interests and institutional interests in disposing of their cases quickly and consensually, so they can pursue other cases or lighten their own workloads. ${ }^{222}$ This reliance on the plea bargain suggests the potential for leverage. ${ }^{223}$ Even the simple act of delaying a decision about whether

216. See supra note 131 and accompanying text.

217. See Bordenkircher v. Hayes, 434 U.S. 357, 364 (1978) ("[S]o long as the prosecutor has probable cause to believe that the accused committed an offense defined by statute, the decision whether or not to prosecute, and what charge to file or bring before a grand jury, generally rests entirely in his discretion."). See also Prosecutorial Discretion, 44 GEO. L.J. ANN. ReV. CRIM. Proc. 269, 269-73 (2015); William J. STUNTZ, The CollapSE OF AMERICAN CRIMINAL JustiCE 257-61 (2011); Wesley MacNeil Oliver \& Rishi Batra, Standards of Legitimacy in Criminal Negotiations, 20 HARV. NEGOT. L. REV. 61, 120 (2015).

218. See Bordenkircher, 434 U.S. at 364.

219. See supra notes 163-66 and accompanying text; see also Prosecutorial Passion, supra note 45 , at 184 .

220. Incompetent Plea Bargaining, supra note 133, at 164-65.

221. William H. Simon, The Ethics of Criminal Defense, 91 Mich. L. REV. 1703, 1707-08 (1993) [hereinafter The Ethics of Criminal Defense] ("[T]he state cannot possibly focus its power ... on all defendants or even most of them.").

222. Incompetent Plea Bargaining, supra note 133, at 164.

223. The Ethics of Criminal Defense, supra note 221, at 1707 ("Libertarian rhetoric tends to 
to accept a deal would provide defendants some time to make a more reasoned choice. Of course, indigent defendants lack power, so before any systemic change could occur, defendants would have to act in concert, in a kind of collective bargaining mode. ${ }^{224}$ This type of coordinated effort is unlikely without a movement among members of the defense bar. ${ }^{225}$ However, the theoretical implications of such a suggestion reveal a hidden weapon that reformers might attempt to wield.

Even on an individual level, defendants may be able to improve his outcome. In cases in which defendants have insisted on representing themselves, empirical evidence suggests that they have been far more likely to resist the plea deal. ${ }^{226}$ Moreover, the available data suggests that the defendants who take control of their cases do as well or better than their counsel-led counterparts. ${ }^{27}$ If the criminal defendant were represented by a lawyer who was not simply constitutionally adequate (a very low bar), ${ }^{228}$ but instead reasonably well-equipped and appropriately motivated, the lawyer might have the ability to gather advantageous information, issue counter-offers, and make credible threats to walk away from the table. ${ }^{229}$

\section{B. Defendant Choice Yields Good Outcomes}

The Constitution is the strongest mandate for empowering criminal defendants to make pretrial and trial decisions, but it is not the only reason to give defendants control. Although the lawyers who populate the bench and the bar not only claim, but assume, that defense lawyers make better choices than their clients, ${ }^{230}$ there is evidence that criminal

suggest that the individual defendant takes on the entire state. But, of course, the state has other concerns besides this defendant. From the state's point of view, the defendant may be part of an enormous class of criminal defendants and suspects with which it can hardly begin to cope.").

224. This is the difficulty with the argument of Robert Scott and William Stuntz that "[e]ach defendant can call on the prosecutor to try the case, forcing her to use time and effort that would otherwise be spent processing other cases." Plea Bargaining as Contract, supra note 2, at 1924.

225. Transaction costs pose a substantial hurdle. Indigent defendants are already disadvantaged in myriad ways, so the obstacles to effective collective bargaining are too many to list.

226. See Defending the Right of Self-Representation, supra note 19, at 451 ("[P] ro se federal felony defendants went to trial (usually jury trial) at approximately double the rate at which represented federal felony defendants went to trial."').

227. Id. at 447-48. See also infra Part VI.C.

228. See supra Part IV.A.

229. In which case the claim that " $[\mathrm{t}]$ he defendant's entitlement [to subject the charge to a full trial] thus motivates prosecutors to bargain - not simply to make offers and walk away" would be valid. Plea Bargaining as Contract, supra note 2, at 1924.

230. Writers have argued that lawyers are simply better decision-makers. See, e.g., John F. 
defendants' decision-making is no worse than that of their attorneys. In 2007, Erica Hashimoto conducted an empirical study examining outcomes in cases in which defendants had represented themselves. ${ }^{231}$ The study contained data from years 1990 through $2000 .^{232}$ Hashimoto concluded that " $[\mathrm{t}] \mathrm{he}$ outcomes for pro se defendants in the State Court Database were at least as good as, and perhaps even better than, the outcomes for their represented counterparts." ${ }^{233}$ Among other findings, the study reported that roughly $50 \%$ of pro se defendants were not convicted of any charge, and of those who were convicted, slightly more than $50 \%$ were convicted of felonies. ${ }^{234}$ In contrast, state court defendants who had counsel were convicted of some charge $75 \%$ of the time (after trial or by guilty plea), and of those who were convicted, $85 \%$ were convicted of felonies. ${ }^{235}$ Hashimoto concluded that " $26 \%$ of the pro se defendants ended up with felony convictions, while $63 \%$ of their represented counterparts were convicted of felonies." 236 While pro se defendants in federal cases do not appear to gain a significant advantage in terms of outcome, they do not do worse than represented clients. Moreover, these defendants are significantly more likely to refuse a plea deal, suggesting that they are enjoying the advantages of greater procedural protections and not paying a price for doing so. Even the Supreme Court has acknowledged that "recent empirical research suggests that [bad outcomes in pro se cases] are not common."237

Although the pro se defendant's success may seem surprising, perhaps it should not be. The lawyer is almost always more sophisticated about the legal issues, but the lawyer is rarely more knowledgeable about the criminal defendant's particular situation. In addition to having unique insight into his own preferences, a defendant also may have particularized information that could tend to affect his chances at trial. This is information that an attorney might be able to

\footnotetext{
Decker, The Sixth Amendment Right to Shoot Oneself in the Foot: An Assessment of the Guarantee of Self-Representation Twenty Years After Faretta, 6 SETON Hall Const. L.J. 483, 598 (1996). See also Resurrecting Autonomy, supra note 189, at 1175 ("The predominance of paternalism over autonomy can be seen both in the Court's decisions and in the academic literature.").

231. Defending the Right of Self-Representation, supra note 19, at 447 (concluding that there is no data proving that pro se felony defendants have worse outcomes at the trial level than represented defendants).

232. Data was taken from even-numbered years. $I d$. at 440 .

233. Id. at 447 .

234. Id. at 448 .

235. Id.

236. Id.

237. Indiana v. Edwards, 554 U.S. 164, 178 (2008).
} 
unearth under certain circumstances - but with limited time and investigative resources, she often does not.

\section{Benefits to Criminal Defendants of Having Control}

\section{The Importance of Client Preferences}

For several reasons, the majority of criminal defendants will have a better experience if they have meaningful control over the disposition of their cases, even if the outcome is not a "success" by traditional standards. These reasons include idiosyncratic (and unknowable) preferences, a respect for the autonomy of the individual defendant, and the psychological benefits of exercising control over one's future. It is virtually impossible for an attorney representing a client to understand all of the considerations that go to the client's preferences. ${ }^{238}$ For example, a client may prefer to go to trial rather than to accept a plea offer because it is important to the client to maintain his innocence. At trial, a defendant may prefer not to call a particular key witness because of a legitimate desire to shield or protect that person. A convicted felon might prefer not to appeal his case because he is sick and tired of the appeals process and seeks closure. As the Court has noted in Faretta, "[t]he right to defend is personal. The defendant, and not his lawyer or the State, will bear the personal consequences of a conviction."239 Not only does the client bear all of the consequences of a conviction, he also has to consider the implications for others, in light of his pretrial and trial decisions. Ultimately, the best result from the defendant's perspective may not always be the best outcome from the attorney's viewpoint. ${ }^{240}$ The most poignant examples are situations in which the defendant prefers not to "fight" a capital conviction. In capital cases, most defendants seek to escape the ultimate sanction, but some do not. The

238. See BINDER \& PRICE, supra note 172, at 148-49 (arguing that because a lawyer cannot know which choices will lead to the greatest satisfaction, decisions should rest with the client); see also Gary Bellow \& BeA Moulton, The LAwyering Process: Materials for CliniCAL INSTRUCTION IN ADVOCACY 103-04 (1978) [hereinafter BELlOW \& MOULTON] (citations omitted) ("The lawyer ... has no reliable way of learning the client's ends on his own. Because these ends are subjective, individual, and arbitrary, the lawyer has no access to them. Because the lawyer's only direct experience of ends is his experience of his own ends, he cannot speculate on what the client's ends might be without referring to his own ends . . ..").

239. Faretta v. California, 422 U.S. 806, 834 (1975). "It is the defendant, therefore, who must be free personally to decide whether in his particular case counsel is to his advantage." Id.

240. Resurrecting Autonomy, supra note 189, at 1178 ("[T] he paternalistic approach takes too narrow a view of what constitutes the best interest of the defendant. In order to conclude that lawyers are more qualified than defendants to make decisions regarding the best possible result for the defendant, one must define the term 'best possible result."'). 
decision of whether to proceed with the presentation of mitigating evidence or to appeal a conviction is intensely personal, and a competent defendant may choose to forgo these tactics. ${ }^{241}$

\section{Personal Autonomy \& Psychological Benefits of Control}

The idiosyncratic needs of each individual are best supported through respect for personal autonomy. ${ }^{242}$ Concepts of autonomy relate to the ability of a person to function as a total, independent human-being, governed by self-determination and personal fulfillment. ${ }^{243}$ Importantly, the autonomous criminal defendant is able to engage in self-reflection with an eye toward some measure of self-determination. ${ }^{244}$ This value was central to the Supreme Court's reasoning in Faretta. ${ }^{245}$ Faretta defines the ability of a criminal defendant to represent himself as an individual right, which is grounded in the "dignity and autonomy" of the accused. ${ }^{246}$

241. For an eloquent argument along these lines, see Richard J. Bonnie, The Dignity of the Condemned, 74 VA. L. REV. 1363, 1387 (1988) ("In the trial context, no less than on appeal, the competent defendant's interest in controlling his own fate, within the constraints imposed by law, should not be completely subordinated to an evanescent societal interest in the integrity of the capital sentencing process. Defense attorneys and trial attorneys should take appropriate steps, regardless of the defendant's wishes, to assure that the definitional predicates for the death sentence are established. Beyond that, however, the competent defendant should be entitled to decide not to avail himself of the opportunity either to develop and present a case in mitigation or to try to persuade the sentencer that this evidence has sufficient weight to call for leniency.").

242. David Luban, Partisanship, Betrayal and Autonomy in the Lawyer-Client Relationship: A Reply to Stephen Ellmann, 90 ColuM. L. REV. 1004, 1036 (1990) (“Autonomy is a hard concept to define, but as a first cut at its intuitive meaning we may say that autonomy means doing what one wants - choosing freely without outside constraints.").

243. John Christman, Autonomy in Moral and Political Philosophy, STANFORd ENCYCLOPEDIA PHIL. (Edward N. Zalta ed. 2015) (citation omitted), http://plato.stanford.edu/archives/spr2015/entries/autonomy-moral/ ("Individual autonomy is an idea that is generally understood to refer to the capacity to be one's own person, to live one's life according to reasons and motives that are taken as one's own and not the product of manipulative or distorting external forces. It is a central value in the Kantian tradition of moral philosophy but it is also given fundamental status in John Stuart Mill's version of utilitarian liberalism.").

244. See, e.g., James E. Fleming, Securing Deliberative Autonomy, 48 Stan. L. Rev. 1, 9 (1995) (concluding that "deliberative autonomy" in our constitutional culture includes the people's "power to deliberate about and decide how to live their own lives, with respect to certain matters unusually important for such personal self-governance, over a complete life.").

245. See Martinez v. Court of Appeal of Cal., Fourth Appellate Dist., 528 U.S. 152, 160 (2000) ("[T] he right to self-representation at trial [is] grounded in part in a respect for individual autonomy.") (citing Faretta v. California, 422 U.S. 806, 834 (1975)); see also McKaskle v. Wiggins, 465 U.S. 168, 176-77 (1984) ("The right to appear pro se exists to affirm the dignity and autonomy of the accused and to allow the presentation of what may, at least occasionally, be the accused's best possible defense.").

246. Faretta, 422 U.S. at 834; James Erickson Evans, The "Flesh and Blood" Defense, 53 WM. \& MARY L. REV. 1361, 1379 (2012) (quoting United States v. Singleton, 107 F.3d 1091, 1102 (4th 
Affording a defendant control over process in his own case also has significant psychological benefits for the defendant. The feeling of control is an important influence on human behavior. ${ }^{247}$ When individuals perceive that they have control over events, they experience less fear. ${ }^{248}$ "[C]onversely, individuals are likely to view risks over which they perceive that they have little influence as more dangerous and less acceptable." 249 In particular, psychological research has found that criminal defendants whose actual participation in their cases was congruent with their level of desired participation were more confident in the process and more trusting of their attorneys. ${ }^{250}$

\section{Courts Recognize Defendant Control}

The late Justice Scalia, a surprising advocate for criminal defendants, once said, "[w]hat the Constitution requires is that a defendant be given the right to challenge the State's case against him using the arguments he sees fit." ${ }^{251}$ This right of self-determination was captured in the Supreme Court opinion in Faretta, in which the Court preserved the right of self-representation, saying "although [the defendant] may conduct his own defense ultimately to his own detriment, his choice must be honored out of 'that respect for the individual which is the lifeblood of the law." ${ }^{252}$ In so doing, the Court acknowledged the Framers' intentional wording of the Sixth Amendment, which affords defendants the right to "assistance of counsel." 253 According to the Court, the choice of language reflected the drafter's desire to give control of the defense to the defendant, and not his lawyer. ${ }^{254}$ In a number of cases, courts have held that where a defendant and his attorney disagree with respect to basic decisions about how to proceed, the interest of the

\footnotetext{
Cir. 1997)) (explaining that Faretta clarifies self-representation is found in pro se defendants' "dignity and autonomy").

247. See George Loewenstein, Out of Control: Visceral Influences on Behavior, 65 Organizational Behav. \& Hum. Decision Processes 272, 274 (1996).

248. See Paul Slovic, Perception of Risk, 236 SCIENCE 280, 283 (1987).

249. Molly J. Walker Wilson, Cultural Understandings of Risk and the Tyranny of the Experts, 90 OR. L. REV. 113, 166 (2011).

250. Marcus T. Boccaccini et al., Development and Effects of Client Trust in Criminal Defense Attorneys: Preliminary Examination of the Congruence Model of Trust Development, 22 BEHAV. SCI. \& L. 197, 206-07 (2004) (finding that incarcerated criminal defendants who trusted their attorneys were more satisfied with their attorneys and their sentences).

251. Indiana v. Edwards, 554 U.S. 164, 184 (2008) (Scalia, J., dissenting).

252. Faretta v. California, 422 U.S. 806, 834 (1975) (quoting Illinois v. Allen, 397 U.S. 337, 350-51 (1970) (Brennan, J., concurring)).

253. Id. at 832 .

254. See Resurrecting Autonomy, supra note 189, at 1148-49.
} 
defendant in controlling his own case was paramount. ${ }^{255}$

Courts have resolved the tension between defendant rights and the imposition of an attorney's choice in a variety of ways. ${ }^{256}$ Some state courts have afforded criminal defendants more control. For example, the North Carolina Supreme Court has held that in a situation in which counsel and client are at an "absolute impasse" about a tactical decision, the client's choice controls. ${ }^{257}$ Other courts have similarly recognized the importance of a defendant's control over process, holding that small strategic choices may legitimately reside with counsel, while significant decisions should, at a minimum, be shared between client and counsel. ${ }^{258}$

One such significant decision is whether to concede guilt in an effort to gain leniency from a judge or jury. In State v. Carter, the defendant was charged with first-degree and felony murder. ${ }^{259}$ Over Carter's objections, his defense counsel told the jury that Carter was involved in the shooting, thereby conceding the felony murder count of the indictment. ${ }^{260}$ The Kansas Supreme Court cited Faretta in holding that counsel's concession "not only denied Carter the right to conduct his defense, but... it was the equivalent to entering a plea of guilty."261 Although courts are reluctant to reverse or order retrial, in circumstances in which a defendant's legitimate choice was hijacked by his lawyer, some courts have crafted a remedy. ${ }^{262}$

255. Jones v. Barnes, 463 U.S. 745, 751 (1983); see also Florida v. Nixon, 543 U.S. 175, 187 (2004) (reaffirming that "certain decisions regarding the exercise or waiver of basic trial rights are of such moment that they cannot be made for the defendant by a surrogate"); Brookhart v. Janis, 384 U.S. 1, 7 (1966) (holding that counsel cannot "enter a plea which is inconsistent with his client's expressed desire and thereby waive his client's constitutional right to plead not guilty and have a trial in which he can confront and cross-examine the witnesses against him").

256. See, e.g., United States v. Davis, 285 F.3d 378, 384-85 (5th Cir. 2002) (holding that a defendant's right of self-representation prohibits the trial court from appointing an independent counsel to present mitigating evidence over the defendant's objection).

257. See State v. Ali, 407 S.E.2d 183, 189 (N.C. 1991); see also State v. Roscoe, 910 P.2d 635, 650 (Ariz. 1996) (noting defendant possessed a "strong privacy interest" in withholding particular mitigating evidence from the sentencing court and finding trial court's order to defendant's counsel to not present certain mitigating evidence was valid); People v. Lavalle, 697 N.Y.S.2d 241, 242-43 (N.Y. Sup. Ct. 1999) (describing criminal process decisions as "fundamental" and belonging to the client).

258. Treece v. State, 547 A.2d 1054, 1058-59, 1062 (Md. 1988) ("[T] he defendant ordinarily has the ultimate decision when the issue at hand involves a choice that will inevitably have important personal consequences for him or her, and when the choice is one a competent defendant is capable of making.").

259. 14 P.3d 1138, 1141 (Kan. 2000).

260. Id. at 1143-44.

261. Id. at 1148

262. The Supreme Court has stated that a remedy for the ineffective assistance of counsel 


\section{E. Strategies for Combatting Bias}

The challenge that defense-attorney bias poses for substantive and procedural justice is considerable. Because the defense attorney is in the best position to protect the defendant, and because the defendant relies exclusively or almost exclusively upon the lawyer to maximize the defendant's outcome, any factor that distorts the lawyer's judgment can have devastating consequences for the defendant. In the aggregate, the internal (psychological) and exogenous (structural) factors that create ethical blindness and motivated decision-making impact tens of thousands of stakeholders. ${ }^{263}$ Moreover, while courts have spent considerable time pondering the importance of portions of the Bill of Rights for the protection of criminal defendants, the "McJustice" criminal adjudication process of which defense attorneys are an integral part makes a mockery of these decisions. Meanwhile, American jails and prisons are overcrowded, and prisoners are often released based not upon the merits of their cases, but in response to changes that have been made by the Federal Sentencing Commission. ${ }^{264}$ While it is logical to reduce prison terms because of sensible restructuring of sentencing guidelines, this method does not account for the fact that thousands of defendants' charges were never meaningfully tested or proved in the first instance. Nor do changes to sentencing guidelines increase the chances that constitutionally mandated protections will be afforded to defendants in the future.

should be "tailored to the injury suffered from the constitutional violation ...." United States v. Morrison, 449 U.S. 361, 364 (1981). See also People v. Curry, 687 N.E.2d 877 (Ill. 1997); State v. Lentowski, 569 N.W.2d 758 (Wis. Ct. App. 1997); Julian v. Bartley, 495 F.3d 487 (7th Cir. 2007).

263. In addition to the defendants themselves, defendants' families, their communities, and the public are negatively impacted by meet-em-and-plead-em practices. Nationally, $48 \%$ of families cannot afford the costs associated with a conviction of a family member. SANETA DEVUONOpowell et al., Ella Baker Ctr. for Human Rights, Who Pays? The True Cost of INCARCERATION ON FAMILIES 7 (2015), http://whopaysreport.org/wp-content/uploads/2015/09/WhoPays-FINAL.pdf. Furthermore, $54 \%$ of inmates have minor children coming to a total of 2.7 million children whose parents are in prison. PeW Charitable TRS., Collateral Costs: INCARCERATION'S EFFECT ON ECONOMIC MOBILITY 4 (2010), http://www.pewtrusts.org/ /media/legacy/uploadedfiles/pcs_assets/2010/collateralcosts1pdf.pdf.

264. The Marshall Project describes the offender release method this way: "[T]he Sentencing Commission's new guidelines essentially instructed the courts to adjust Doe's offense level downward by two levels, which in turn meant that his sentence could be reduced, too. For instance, if Doe trafficked 80 to $<100$ grams of heroin, he used to be a Level 24 offender, and he was sentenced to prison for 51 to 63 months. When the guidelines changed, he was adjusted downward two levels to a Level 22 offender, and he was now eligible for a new sentence of 41 to 51 months." What You Need to Know About the New Federal Prisoner Release, MARShall ProjeCt, https://www.themarshallproject.org/2015/10/06/what-you-need-to-know-about-the-new-federalprisoner-release\#.FSkCEPVDd (last updated Oct. 29, 2015, 9:27 AM). 
A review of scholarship on the problem of defense attorney bias reveal two categories of solutions. Traditional solutions are generally tied to legislative, executive, or administrative action to alleviate the problems of plea bargaining, such as judicial oversight or increased funding for public defender offices. Non-traditional solutions attempt to address the attitudes or mindsets of the public defenders themselves. Very few of the proposed solutions have contemplated behavioral science findings; when this research is taken into account, it becomes clear that some remedies are more viable than others.

One popular solution to counteract our current system of McJustice is increased judicial oversight. In the Lafler and Frye decisions, the Supreme Court paved the way for increased judicial oversight of criminal proceedings leading up to trial. ${ }^{265}$ In these cases, the Court seems to have acknowledged a need for greater regulation of plea-bargaining, concluded that procedural fairness was of constitutional significance, and trusted case outcomes to gauge prejudice. These changes are crucial "to the broader task of reframing guilty plea adjudication" with methods that are both realistic and aligned with established constitutional standards. ${ }^{266}$ Scholars suggest these decisions manifest a belief on the part of the Court that judicial oversight of plea bargaining will decrease the amount of bias exhibited by both the prosecutor and the defender. ${ }^{267}$ Examined through a behavioral science perspective, however, judicial oversight appears inadequate to address the failure of process created by the ubiquitous plea bargaining system. Judges, no less than public defenders and prosecutors, are susceptible to biases that skew their treatment of indigent defendants. ${ }^{268}$ Overcrowded dockets motivate judges to prefer plea bargains, just as heavy caseloads create incentives for prosecutors and defense attorneys. ${ }^{269}$ As such, giving judges more oversight and

265. See Joel Mallord, Putting Plea Bargaining on the Record, 162 U. PA. L. Rev. 683, 690-92 (2014); Wesley MacNeil Oliver, Toward a Common Law of Plea Bargaining, 102 KY. L.J. 1, 44-45 (2014).

266. Anne R. Traum, Using Outcomes to Reframe Guilty Plea Adjudication, 66 FlA. L. REV. 823,824 (2014).

267. See Shadow of Trial, supra note 34, at 2542-43.

268. For evidence that judges exhibit decisional biases, see Avani Mehta Sood, Motivated Cognition in Legal Judgments-an Analytic Review, 9 ANN. REV. L. \& Soc. SCI. 307, 308, 318-19 (2013) (identifying factors that can motivate legal judgments); Andrew J. Wistrich et. al., Heart Versus Head: Do Judges Follow the Law or Follow Their Feelings?, 93 TEX. L. REV. 855, 898-900 (2015) (providing judges - like jurors - are influenced by their own emotional reactions to litigants); see also Chris Guthrie, Symposium, Misjudging, 7 NEV. L.J. 420, 448 (2007); Avani Mehta Sood, Cognitive Cleansing: Experimental Psychology and the Exclusionary Rule, 103 GEO. L.J. 1543, 1572-87, 1608 (2015).

269. In the most recent report on federal court caseloads, there were over 456,000 cases pending in federal district courts, and federal district judges handle 675 pending cases per year on 
control over the plea bargain negotiations will likely prove fruitless in stemming the tide of plea bargains. Even more judicial review of initial charging decisions ${ }^{270}$ would likely change little, given that judges have difficulty "disbelieving" information that is primed early, just as other human beings do. ${ }^{271}$

Another proposed solution is to increase funding for public defenders' offices. $^{272}$ Providing public defenders greater resources would lessen the constraints that make actors particularly susceptible to bias. Moreover, providing defense attorneys resources to investigate clients' cases would decrease the motivation to dispose of cases quickly and give them tools to gather potentially exculpatory evidence. However, increasing funding for any government department is difficult, and elected officials have little incentive to funnel tax dollars away from infrastructure, law enforcement, and other services to benefit indigent defense. ${ }^{273}$

On the other hand, "non-traditional" solutions to public defender bias highlight the intractability of human cognitive predispositions. One such line of proposals involves increasing public defenders' motivation to work hard for their clients. An article by Charles Ogletree, Beyond Justifications: Seeking Motivations to Sustain Public Defenders, ${ }^{274}$ was followed by a piece by Abbe Smith, Too Much Heart and Not Enough Heat. ${ }^{275}$ Ogletree and Smith argue that the most effective way to eliminate plea deal injustice is to instill the public defenders with various emotional motivations such as heroism, empathy, respect, and professionalism. ${ }^{276}$

While empathy and heroism are powerful emotions that can inspire

average. National Judicial Caseload Profile, U.S. COURTS (June 30, 2016), http://www.uscourts.gov/file/20172/download.

270. See, e.g., Robert Heller, Selective Prosecution and the Federalization of Criminal Law: The Need for Meaningful Judicial Review of Prosecutorial Discretion, 145 U. PA. L. REV. 1309, 1332-33 (1997).

271. Andrew J. Wistrich et al., Can Judges Ignore Inadmissible Information? The Difficulty of Deliberately Disregarding, 153 U. PA. L. REV. 1251, 1251 (2005).

272. See Mary Sue Backus \& Paul Marcus, The Right to Counsel in Criminal Cases, A National Crisis, 57 HASTINGS L.J. 1031, 1046-59 (2006).

273. In her impassioned appeal for an increase in funding for Missouri's Public Defenders office, Justine Finney Guyer argues that an increase in funding is so imperative so as to justify judicial action to circumvent the inaction of the legislature. Justine Finney Guyer, Saving Missouri's Public Defender System: A Call for Adequate Legislative Funding, 74 MO. L. REV. 335, 356 (2009).

274. Charles J. Ogletree, Jr., Beyond Justifications: Seeking Motivations to Sustain Public Defenders, 106 HARV. L. REV. 1239 (1993).

275. Abbe Smith, Too Much Heart and Not Enough Heat: The Short Life and Fractured Ego of the Empathic, Heroic Public Defender, 37 U.C. DAVIS L. REV. 1203 (2004).

276. See Ogletree, supra note 274, at 1289-94; Smith, supra note 275, at 1243-59. 
action, they require a foundational belief in the correctness of a certain outcome. Even assuming that a defense attorney is sympathetic to her client's situation and invested in his well-being, she will not be convinced that rejecting a plea deal is wise unless she is convinced that she can present evidence that will make acquittal likely. She will not be motivated to spend her time looking for exculpating evidence and building a case for trial unless she thinks that her client will be served by such efforts. Instead, she may spend that time providing other advice and services that she believes (however mistakenly) are most helpful to the client. In other words, priming, anchoring, belief perseverance, and other biases will create a set of beliefs that will guide her strategy, regardless of how compelling she finds her client's predicament.

Solutions that impose limits upon the human beings who decide a defendant's fate are more promising because they do not rely upon counteracting biases that have proven virtually intractable. In his article Fixed Justice, for example, Russell Covey argues that the best course of action is to limit the ability of a prosecutor to pressure a defendant to take a deal by threatening him with a disproportionately severe sentence if he goes to trial. ${ }^{277}$ According to Covey, restricting prosecutors' ability to use scare tactics would increase the likelihood that indigent defendants will choose to take their chances at trial, where the substantial burden remains on the prosecution. ${ }^{278}$ As examined through the behavioral science lens, Covey's proposal seems to have promise. A plea ceiling would bind all prosecutors, effectively neutralizing their cognitive biases concerning the guilt or innocence of the client. Without the threat of an extreme sentence hanging over him, a criminal defendant would gain a measure of control that he does not have in the current system, allowing for more informed choices about whether or not to accept a plea bargain.

\section{CONCLUSION}

Criminal defense lawyers operate under professional pressures that originate and are perpetuated by several features of the criminal justice system. Although there is widespread awareness of the current crisis in criminal defense, the criminal justice system is not equally responsive to all stakeholders, nor is it all that responsive to changes in the law, because the incentives remain fairly stable. ${ }^{279}$ Serving the needs of many

277. Russell D. Covey, Fixed Justice: Reforming Plea Bargaining with Plea-Based Ceilings, 82 TUL. L. REV. 1237, 1281-84 (2008).

278. Id. at $1246-51$.

279. Consider William J. Stuntz, Plea Bargaining and Criminal Law's Disappearing Shadow, 
clients with varying situations, the demands of negotiating in high-stake situations, and severe time limitations require public defenders to take shortcuts and to make educated guesses about how to allocate their time. The Bureau of Justice reports that more than $68 \%$ of criminal defendants are represented by a public defender, ${ }^{280}$ and of those with public defense, more than three-fourths plead guilty. ${ }^{28}$

This number is suspiciously high. Either defendants are getting fantastic bargains by accepting pleas - a hypothesis that seems unlikely based upon prosecutors' own admissions ${ }^{282}$ —or distortions are occurring during pretrial decision-making. ${ }^{283}$ In fact, research suggests that defendants should be predisposed to disfavor pleas. Loss aversion, the empirically demonstrated idea that human beings are irrationally disposed to avoid certain losses, indicate that plea deals should be distasteful. ${ }^{284}$ Defendants should prefer to take their chances at trial. Furthermore, in accepting a plea, the defendant gives up rights that have both expressive and instrumental functions.

In ceding the right to trial, the defendant surrenders his "day in court." The opportunity to force the state to make its case against the defendant is a valuable entitlement, as evinced by the fact that the

117 HARV. L. REV. 2548, 2552 (2004) ("A lot of criminal litigation does not fit this straightforward pattern. Imagine a jurisdiction where the legally mandated sentence for robbery with a firearm is ten years in prison, meaning that judges must impose that sentence for that crime. Prosecutors remain free to charge a variety of different crimes, each of which carries its own mandatory sentence. Imagine further that prosecutors in this jurisdiction believe that defendants who are guilty of robbery with a firearm deserve five years in prison. Conveniently enough, simple robbery carries a sentence of five years. In order to preserve their bargaining power, prosecutors are willing to impose the tenyear sentence on robbery-with-a-gun defendants who go to trial and lose, but they believe the right sentence is five years. Finally, imagine that prosecutors in this jurisdiction operate under severe resource constraints. They lack the time to prosecute all the winnable cases they have. Consequently, prosecutors only prosecute when they have at least a $75 \%$ chance of winning at trial. Weaker cases are dismissed.").

280. U.S. DeP'T Justice, Bureau of Justice Statistics Special Report: Defense COUNSEL IN CRIMINAL CASES 1 (2000), http://www.bjs.gov/content/pub/pdf/dccc.pdf.

281. Id.

282. See supra notes $14-15$ and accompanying text.

283. See Frye and Lafler, supra note 124, at 26, and accompanying text.

284. See Amos Tversky \& Daniel Kahneman, Advances in Prospect Theory: Cumulative Representation of Uncertainty, 5 J. RISK \& UNCERTAINTY 297, 311 (1992). The foundational work on the theoretical basis for decisions under uncertainty was Daniel Kahneman \& Amos Tversky, Prospect Theory: An Analysis of Decision Under Risk 47 ECONOMETRICA 263 (1979). But see the pure economic analysis provided by Richard Birke:

The economically-minded defendant pleads guilty presumably because the certain value of the plea is better than the expected value of the trial. The defendant compares the value of the plea $(\mathrm{Vp})$ with the expected value of trial $(\mathrm{EVt})$ and chooses whichever option yields more utility. The value of the plea can be known with a high degree of certainty ....

Reconciling Loss Aversion, supra note 152, at 216. 
prosecutor is willing to "pay" with a discounted sentence in order to avoid it. Another cost to the defendant when he gives up the trial is his required admission of guilt. ${ }^{285}$ A criminal defendant who goes to trial can, regardless of the outcome, maintain his innocence. Conceding guilt in open court-particularly for defendants who are innocent-is an act that comes with considerable psychological and social costs. To counteract loss aversion and other factors disadvantaging the plea, significant pressures must be brought to encourage the deal. ${ }^{286}$ Evidence suggests that often, these pressures, whether subtle or overt, originate with the defendant's own lawyer. ${ }^{287}$

Theoretically, it is possible for a prosecutor and a criminal defendant to arrive at an agreement in which both sides are well served. ${ }^{288}$ However, the conditions under which most criminal defendants and their attorneys operate make this outcome unlikely. Bargains that are well informed and constitutionally sound require adequate resources to investigate allegations, sufficient time to file appropriate motions, thorough discussion between lawyer and client, and most importantly, defendants who feel free to reject the plea offer and proceed to trial. Ultimately, "adversarial testing requires defense lawyers to probe prosecutors' cases, dicker over their offers, and advocate for the most favorable outcomes available in the plea-bargaining market." 289 This rigorous model is far from the one that our plea-bargain-ridden and indigent-defendant ripe system promotes. Instead, over-burdened, underresourced defense attorneys doggedly try to keep pace with the steady stream of low-income, underserved clients.

A wealth of social science data establishes that distortions in

285. The exception is the nolo contendere plea. See 1A ChARLES AlAn Wright \& ANDREW D. Leipold, FedERAL PRACTICE AND PROCEDURE $\$ 175$ (4th ed. 2008) (stating nolo contendere "is not an admission of factual guilt").

286. Lucian E. Dervan \& Vanessa A. Edkins, The Innocent Defendant's Dilemma: An Innovative Empirical Study of Plea Bargaining's Innocence Problem, 103 J. CRIM. L. \& CRIMINOLOGY 1, 17 (2013) ("It is unclear how many of the more than $96 \%$ of defendants who are convicted through pleas of guilt each year are actually innocent of the charged offenses, but it is clear that plea bargaining has an innocence problem.").

287. See Reconciling Loss Aversion and Guilty Pleas, supra note 152, at 219 (describing the "rational" process for deciding to accept a plea: "A rational, well-informed defendant should plead guilty only if the value of the plea is better than the expected value of trial, and after an adjustment has been made to account for the defendant's diminishing sensitivity to the most distant units of punishment."). Contrast this process with the reality of the hurried meeting and poorly informed consultation. MOTHER JONES, supra note 10.

288. Pareto efficiency is achieved when all sides are better off, and no side could be made better without one side being made worse off. Pareto Efficiency, INVESTOPEDIA, http://www.investopedia.com/terms/p/pareto-efficiency.asp (last visited Oct. 10, 2016).

289. Incompetent Plea Bargaining, supra note 133, at 169. 
judgment occur under circumstances like those facing public defenders. Given what we know, there is good reason to worry about the attorneychoice model. Defense attorneys and courts should advocate for a greater role of the defendant in making decisions-particularly when plea deals are on the table. Public defenders should encourage their clients to consider their own preferences in the decision-making context. Courts should adopt a skeptical view of decisions made exclusively by defense lawyers, particularly when the client has objected to the lawyer's choices. Courts should also be willing to consider overturning plea deals when there is evidence that psychological and emotional pressure was a factor in getting the defendant to plead guilty. Returning decisionmaking power to the criminal defendant would mean fewer innocent people in prison, better psychological outcomes for criminal defendants, and a more ethical and accurate process of meting out criminal justice.. 